\title{
JUMALA JÄLGEDEL
}

\section{Peko lahkumine}

\author{
HEIKI VALK
}

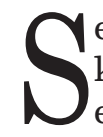

ee lugu sai alguse 1993. aastal Setomaal Meremäe lähedal Uusvada külas. Siis toimunud kohtumine samas paigas sündinud Anne Linnupuu ehk Linnupuu Annega ${ }^{1}$ (neiupõlvenimega Luuga, 1932-2009) andis mulle esimese vahetutel mälestustel põhineva kokkupuute Pekoga, luues pinna hilisemaks huviks ja edasisteks küsimisteks. Pärast pikemat vaheaega sai toona episoodiliseks jäänud lähenemine uue tõuke jutuajamistest Ermakova külast pärit Heino Keskkülaga (snd 1943) - mehega, kellel on Setomaal olnud võimalus näha koguni mitut Peko kuju veel elava ja austatava jumala, mitte unustatud eseme või museaali rollis.

Peko on olnud teema, millest võõrale ei räägita. Need, kes Pekost avalikult kõnelevad, on kõrvalseisjad, ja teadmise mõjul, et Peko „ei tahtvat, et temast kellelegi võõrale räägitakse ehk teda näidatakse” (Speek 1930: 149), on jäänud toimumata mõnedki jutuajamised ning esitamata ja vastamata mõnedki küsimused. Ühel juhul, kui küsides jõudsin otsesõnu Pekoni, katkes telefonikõne. Teema tundlikkus on mõjutanud ka käesoleva loo sisu: kirjutatud pole kaugeltki kõigest ja mitmelgi juhul on otsustatud anonüümsuse kasuks. Minevikku puudutava teadmise osas on vaid kaks võimalust: selle kadumine koos mäletajatega või talletamine ja hoidmine. Ajaline distants on nüüdseks ehk piisav, et vaadata tagasi lahkuva jumala jälgedele ja tuua pudemetena kogunenu trükisõnasse.

Käesolev artikkel teeb kokkuvõtteid setode muistse jumala kohta alates 1990. aastatest peamiselt Obinitsa ümbruses kuuldust ja kõneldust, täiendades varasemaid teadmisi nii Peko kujudest kui ka Peko kultuse ulatusest selle lõpuaegadel. Suur osa järgnevast rajaneb siiski sellel, mida olen Setomaal ja sealt pärit inimestelt kuulnud alates 2016. aastast - ajal, kui olnu uurimiseks oli õigupoolest juba liiga hilja, sest need, kes teadsid Pekot, on lahkunud, ning puust jumalakujudega kokkupuutunuidki enam peaaegu pole. Põhjust kirjutamiseks annab ka tõsiasi, et viimastel kümnenditel on Peko nimi Setomaal ja laiemaltki saanud tänu Anne Vabarna eeposele ${ }^{2}$ algsega võrreldes hoopis uue, Petseri kloostris magava Setomaa jumalkuninga tähenduse. Püüdkem järgnevalt meenutada ka seda Pekot, keda Setomaal tunti enne viimase veerandsajandi metamorfoose.

Teadmine Pekost - vilja ja karja jumalast, õnnetuste eest kaitsjast ja õnne andjast, kelle austamine on seotud kujuga ning varem avalike, hiljem aga sala-

${ }^{1}$ Seto vana kultuuriruumiga tugevamalt seotute nimed on artiklis sageli ära toodud traditsiooniomaselt: enne perekonna-, siis eesnimi. Laiemalt tuntud nimed on esitatud tänapäevasel viisil.

${ }^{2}$ Peko. Setu rahvuseepos. Setukaiseepos. The Setu epic. Laulnud Anne Vabarna. Toim Paul Hagu, Seppo Suhonen. Kuopio: Snellman-instituutti, 1995. 
jaste pidustustega - jõudis eestlasteni koos „seto vendade” avastamisega XIX sajandi lõpukümnenditel ja XX sajandi alguses. Kuuldused ja teated Pekost (Truusmann 1890: 38-39; Sandra 1908; Eisen 1906, 1908) aitasid heita pilku veel elavasse uskumusmaailma. 1934. aastal ilmunud Gustav Ränga artikkel „Materiaalne Peko" sündis tänu asjaolule, et aasta varem õnnestus uurijal Eesti Rahva Muuseumi kogudesse osta Peko kuju Meremäe vallast Krantsova külast. Kaks aastat hiljem ilmus postuumselt Matthias Johann Eiseni artikkel uuematest andmetest jumala kohta (1936).

Seejärel jäi Peko mõneks ajaks teadusliku tähelepanuta, ${ }^{3}$ kuni oma kodukoha läheduses austatud jumala vastu hakkas huvi tundma Paul Hagu. Setomaa muistne jumal sai taas uurijahuvi osaliseks nii seto agraarkalendri ja kombestiku võtmes kui ka soome-ugri rahvaste kultuuri laiemal taustal (Hagu 1975). Hiljem ilmunust tuleb esile tuua Peko kultuse varasema tuntuse kohta kirjutatut (Hagu 1997; Västrik 2017: 526-531).

\section{Ignasõ küla Peko}

Kogukondlikke Peko palvuseid peeti Setomaal teadaolevalt kõige kauem Obinitsast lääne poole jääva Mokornulga ${ }^{4}$ Ignasõ külas. Järgnevalt püüan heita valgust nii toimunule kui ka viimase Peko pidaja Peeter Otsa ehk Otsa Petra isikule, kelle nimi kajastub kõnesolevas seoses juba nii 1931. aasta ajelehesõnumis (Vanas usus...) kui ka 1950. ja 1960. aastate rahvaluuleteadetes.

\subsection{Viimased pidustused}

Peko kultuse varasemates kirjeldustes on üks keskne teema talust tallu ringleva jumalakujuga seotud pidustused ja uue Peko peremehe valimine vereliisuga: kuju valdajaks saab see, kellel ööpimeduses toimunud rüseluse ja üle aia hüppamise käigus esimesena tahtmatult veri välja tuleb (Eisen 1908: 381-385, 1936; Hagu 1975: 166-167). Kuigi varasemate kirjelduste kohaselt olid Otsa ${ }^{5}$ rehes toimunud Peko pidustused samuti seotud vereliisuga (Sillaots 2008: 81), ei ilmne see enam hilisemaid palvusi kajastavates kirjeldustes.

Oli ollu üts poosle, vanaaigne küünlajalg. Irvitiva, et „läts pekole”, „läänu-ks pekole”, „läänu-ks peko poole”. Egäl ütel küünlajalga es ole. Ütsainus jalg oll’,

3 Tõsist huvi tundis Peko vastu 1937. aastal Pariisi Inimese Muuseumi lähetusel Setomaal välitöid teinud Boris Vilde, kes kavatses kirjutada sel teemal Pariisi ülikoolis doktoritöö. Saabunud sõda tegi kavandatu võimatuks. Vilde lasti 1942. aastal maha ning tema välitöömaterjalid Meremäe vallast ei ole säilinud.

${ }^{4}$ Piirkonna nimetus varieerub: ka Mokorluga, Mokroluga, Mokoluva, Mokoluga nulk, samuti Mokolnulk. Setomaa külanimede esitamisel on üldjuhul eelistatud vana rahvapärast nimekuju, mis on raamatus „Setomaa kohanimed” esimesena ära toodud. Tegemist pole ainuõige nimevariandiga, vaid ühega võimalikest. Arhiiviviidetes on säilitatud külanime sealne, sageli kirjakeelepärane esitusviis.

${ }^{5}$ Tegemist on perekonna-, mitte talunimega. Erinevalt Eesti- ja Liivimaast ei ole seto traditsioonis talunimesid: majapidamisi määratletakse seal elava(te) inimes(t)e nime järgi. Elavas keelekasutuses võib tõdeda perekonnanime saamist talunimeks. 
too anti ütest talost tõise. Hüä kui jousid üte vuuri pitä', kattõ-ks olõ-s konagi. Sinna-ks vaja liha tappa. [---] Käisi vana mehe ja naise. Tõisi lasta-s kaema. Lätsi ne', kes terä anni. Kes and kesvi, kes and rukkid, kes and viinaraha. Viidi saia, võidu, munnõ. Pei rehes, aidas, tares. Otsa pei rehes. Tarrõ võis minna egaüts, a kos peetäs, sinna es lasta. Poisi ai iks, et lää kae, a paja oll kinni pantu. - Too tarõ oll' sisest är ehit lehissiga. Sääl olli üts lugeja vai papi iist. Palssi, seie, sõss jäll palssi. Mito anomat olt oll tett. Tal oll ollõanomil üts arv. Ollõ anoma olli põrmanda pääl. - Sõss tulli vällä. Ku na säält vällä tullit, joba valgõl, sõss lätsi aida. Naisõ lätsi kapstamaalõ, poisi lätsi uibodõ ala. Ku na lätsi aida, sõss poisi võtt’ uma ollõ, naisõ uma ollõ. Olli kõtuli maah. Poisi jõi viina, and naisilõ ka. - Laulti ja tandsiti. Käüti tanomit piti ja lauleti. Mitte mida es olõ-s halvusõ poolõst. [--- ${ }^{6}$

EKM ERA, RKM II 44, 503/6 (1) < Setumaa, Meremäe v, Obinitsa k - Udo Mägi < Matro Uibokand, 70 a, Hilana k (1953)

Obinitsa (kandi) nulga Otsa Piitrel oll' ka' vahast valõtu alusel puujummal. Tä hoit' rehetarõh. Üüse käve' salahuisi tuud jumalat pallõmah, õt kasusi' hüä vili, maru murrasi-i' aŕ viljä maaha. Vahel hoit' timä tuud ka' viläaidah. Parembit sõpro kutś ka' viil hindä poolõ, õt nuu' ka pallõsi' hüä viläsaagi iist. Loeti raamatist kol' kõrda, jummal käeh ja käüti niimoodo ümbre küündle, mis tuulaiga panti palama. Kõkõ rohkõmb pallõldi keväjält, inne vilä mahategemist, põvva aigu ka. Tõsõ', kiä tulliva' ka pallõma, tõiva' üteh kanamunnõ, panti saŕa sisse, raputati pallõmise aigu, peräst pallõmist jaotati nuu' tagasi. Inne tuud pallõmist kogoti viljä Peko auks, tetti olt, juudi. Otsa naane küdsi pliine, anti nuid süvvä' kõigilõ. Tuust pallõmisest es tohi' tõistõlõ midägi kõnõlda. Kuulda' om, õt nokki [nüüdki] om tuu Pekojummal viil timäl kotoh.

EKM ERA, RKM II 247, 174/5 (4) < Obinitsa k - Nikolai Repän < Masti Hemmo tütar, u 50 a (1960/1967)

Ignasõl kohtasin 1996. aastal naist, kelle vanaema oli emalt kuuldu kohaselt Peko pidustustel käinud. Palvusele mindi pärast sauna ja sinna pani vanaema selga seto rõivad. Kindlasti pidi ees olema põll ja peas linik. Söök, ju siis kausiga, oli kaasas neljast nurgast kompsuks kokku seotud rätiku sees. Sealjuures ei olnud vanaema kohalik, vaid võetud naiseks Petseri tagant Potalova külast. Jutustaja vanaisa, oma küla inimene, ei olevat Peko teenistustel käinud. (Valk 1999: 157)

1994. aastal mäletati, et viimastele Peko palvustele käidi ka Kõõrult, kuid osavõtjate ring piirdus vanade inimestega.

A.L.: Ignasõ küläh Pekot pallõldi... käve’ kõik vana' inemise' sinnä' kokko.

M.S.: Tuu oll' sääne vaha kuju tettü, sis sinnä' lätsi', ma ei tiiä, mis üül nä' lätsi', mul ka tuud ei olõ' meeleh... Lätsi'... sääntse' vana' inimese'. Aga noh, meil es olõ' tuud muudu, et mi lätsi'. Mi ei tiiä' mitte midägi...

A.L.: Üüse nä' vast käve', üüse käve' vai?

${ }^{6}$ Seto murdetekstide ortograafiat on vajadusel korrastanud ja ühtlustanud Paul Hagu, kes on samuti avaldanud pikema kirjelduse viimastest palvustest Ignasõl (Hagu 1975: 167). 
M.S.: Üüse vast ja õdagu, tah oll’ , näet... Mi küläh ka oll’ mõni sääne inemine, kes läts...

EKM ERA, FAM 103 (31) < Meremäe v, Kõõru k - Mari-Ann Remmel < A.L. (naine, 84 a) ja M.S. (naine, 73 a) (1994)

Viimased Peko pidustused toimusid Obinitsa kodu-uurija Liidia Sillaotsa (1933-2016) järgi Otsa rehes kas aastal 1932 (Sillaots 2008: 81-82) või 1933 (Obinitsa, 1996*). ${ }^{7}$ Siiski võidi väiksemas ringis ja vaikselt kokku tulla hiljemgi. Ajalehe Uus Eesti teatel olevat „mõnes Setumaa nurgas” Peko austamine jätkunud veel 1938. aastal (Eesti Rahva Muuseum...).

Ühte viimastest kogunemistest Otsa pool vahendavad Võru Helmekaala' laulukoori rajaja ja eeslaulja, Tääglüvä külast pärit Linnupuu Anne mälestused (Võru, 2017*). ${ }^{8}$ Anne sattus koos Ignasõl karjas oleva õe ja teiste lastega Peko pidustustele umbes kümnesena, seega 1935. aasta paiku. Suvisel õhtusel kogunemisel olid tares vaid vähesed sama küla vanad inimesed. Lapsed vaatasid toimuvat üle ukse maja eesruumi ehk seenisesse tehtud köögist, ära neid ei aetud. Valge linaga kaetud kuju ei seisnud ukse vastas olevas pühasenurgas, vaid taga seina ääres sellest vasakul, toa sisemise nurga pool. Sündmus ei kestnud kaua ja öösse ei ulatunud. Selles seoses mainib Anne ka Peko „tõstmist" - kuju edasiviimist ühest talust teise.

Ma olli, noh, lats. Ku suur ma õks olli, midä suur?... Ignasil peeti tuud Pekot. Peko. [---] A ma mälehtä ütte, ütte tallo. Ma olli nii ku Laine puul. Sis kas oll’ sõsar kaŕah vai Laine puul sääl? Olli sis nõstõtu Pekot. Üts valgõ midägi nukah oll' linah, ma tuud käega putu-s vai näe-s. A tuud ynnõ mälehtä, õt süüki viidi. [---] Rahvast tull' kokko, uma külä'. Tõisi ma es tiiä'. Nii pall’o ku neid oll’. A tuud om meeleh, kausiga naistel oll’ räti seeh. A mis sääl oll’, kas sõir vai kohupiim vai...? [---] No pall’o sääl Ignasil oll’? Ega pall’o väega es olõ'. Tuu tarõgi olõ-s suur ja tuu valgõ linaga oll’ õkva sääl nulga puul. No kas kuus inemist vai - pall’o sääl küläh oll'. Kas kõik oll' vai, tuud ma tiiä-i. Jaah. [---] A nii, jah, sääl õt nõstõti nii. Üte talo puult läts tõõsõ. Kas nädäli peräst vai, viidi jal tõsõ puulõ. Nii ütli'. Kuuli, õt nõstõti, õt kas tä rassõ ka olli? A ütli', õt aŕ varastadi. Tuu oll' yks vahanõ, vahast tettü. [Otsa] Petrat tuul-aiga õdagul es olõ' sääl. [---] A tuud ma näi, õt taah om Peko! Lina oll’ nii ja... Räti seeh viidi sinnä ja sääl midägi oll’. A kas sääl aŕ süüdi vai - ka ei olõ' meeleh. [---] A muido ma olõ käünü' sõsaraga üteh sääl. Ni lats näe-es, naisil oll’ üteh midägi, üteh sei' vai panti tuud... A Pekot oll', Ignasil. [---] A vot ma ka ei tiiä', määndse õdagu. Nädäli seeh nii käüti. Ja tuud sis nõstõti. Ja sis jal tõsõ talo puulõ nõstõti. [---] Olõ-s taa yks õdagu kavva. Selle nii ku õdagu yks minti ja minti, sis õdagu tagasi. $\left(2017^{*}\right)$

Õlgkatusega rehi, kus toimusid viimased Peko teenistused, süttis Otsade naabertalus elava Leoste Pauli (snd 1939) sõnul põlema rehepeksu ajal traktori korstnast lennanud sädemest 1948. aasta sügisel (2018*). Siis aga Pekot seal enam ei olnud - juba enne sõda oli Otsa Petra läinud elama naaberkülla

\footnotetext{
${ }^{7}$ Siin ja edaspidi tähistab aastaarvu juures olev tärn (*) autorile kõneldut.

${ }^{8}$ Mitte avalõigus nimetatud Linnupuu Anne Uusvadast, vaid tema nimekaim ja mehepoolne sugulane, sündinud aastal 1925.
} 
Navigõle, kuhu ta viis ka jumalakuju. Elumaja, kus toimunud Peko pidustust Linnupuu Anne nägi, on samuti põlenud: Paul mäletab, et rehest allatuult kandunud tules hävisid hoone katus, sarikad ja otsaviilud (2018*). Siiski õnnestus hoone kustutada ja ehitati uuesti üles. Kolm välisseina on Peko aegadest tänini alles.

\subsection{Jumala kadumine}

1930. aastatel lõppesid Ignasõl Peko teenistused ja kuju kadus avalikkuse eest. See andis kohalikule rahvale kõneainet ja jutud Peko varastamisest levisid juba enne sõda. Kuju vargusest on kõneldud vähemasti Tal'kas, Härmäl, Kõõrus, Tääglüväs ja Obinitsas: „Säält ta läts kaoma kah, sis Ignasõlt vai Navigõlt. [---] Varastadi ära. Viidu üüse salaja. Kes teda sis hoidse ja..." (Härmä, Aksel Haavik, snd 1944). Räägitud on kuju müümisest Soome. Peko kadumine tekitas vanemates inimestes pahameelt: „Ignasõ küläh olli veel, möi ar Tartohe. Vanõmb rahvas oll’ pahane" (EKM ERA, RKM II 44, 507 (1) < Andrekova k - Udo Mägi < Andrei Lõhmus, 61 a (1953)). Rahva kahjutunnet Peko kadumise üle väljendas ka Võrus elav Linnupuu Anne.

Ku ma kotoh olli viil, sis kynõldi, nii ku käve kerikoh vai, nii, näät, õt Peko varastadi aŕ. [---] Jah, tuu oll' yks Eesti aigu, tuu jutt, Peko varastaminõ. Tuud kynõli' vanõmba' mi puul sis. [---] A tuud sääl kynõldi, õt aŕ varastadi. Oll' tuud, kas keriguaigu ka vai, rahvas läts. Et rahval nii ku oll’ kah'o vai, õt kes tedä võtt’ vai kohe tä jäi. $\left(2017^{*}\right)$

Peko kadumise kohta 1944. aasta sõjasuvel Ignasõ külas kõneldu on ühetaolise sisuga: „Üks kui teine sama küla elanik üleb, et Peku-kuju jäänud Peeter Otsa kätte, kes oli sellel aastal aga kirikuteener ja üldse ei taha mäletada Pekot" (EKM ERA, RKM II 14, 101 < Ignase k, Liis Pedajas (1944/46)). Kes teab, ehk oligi Peko ootamatu avalikkuse eest kadumise põhjuseks tema pidaja uus või eesseisev amet? Otsa Petrat on Peko kadumisega seostatud mälestustes hiljemgi, näiteks 1996. aastal Ignasõl: „Piitre möi maaha, tä sai pall’o raha, kynõldas” (Valk 1999: 155) ja Tääglüväs: „A Peko oll’ Ignasil ja säält sis varastadi aŕ. Peräh oll’ tuu hätä midägi, õt kohe tä yks jäi. Kynõldi, et Otsa Pets vei aŕ vai..., olõvat aŕ varastanu" (Linnupuu Anne, 2017*).

Samas nähtub ühest jutuajamisest, et jutte Peko varastamisest võis juba 1940. aastatel levitada kuju viimane valdaja ise.

M.S.: Aga noh, aga sis see vaha oli nii suur olnu ja sis varastati see aŕ säält...

Üteh reheh olli olnu, kos vanast riihi peksti vai... [---] Näet, tuu, mis tuu kerikumiis oll', kuis timä kutsuti, [---] Petra, jah. Noh, tuu ütskõrd selet' meile ka, kuis tä oll'.

A.L.: Tuu oll' õks vääga ammu jo.

M.S.: Tuu vast oll'gi tuu varas, viijä.

A.L.: Määne viiskümmend aastat tagasi, mi ei tiiä'...

EKM ERA, FAM 103 (31) < Setomaa, Meremäe v, Kõõru k - Mari-Ann Remmel $<$ M.S (naine, 73 a) ja A.L. (naine, 84 a) (1994) 
1974. aastal Otsa Petrat kui Obinitsa kiriku endist küünlamüüjat küsitlenud Paul Hagule väitis asjaosaline, et kuju oli ammu, juba enne sõda kaduma läinud.

Rahva seas liikusid jutud kuju varastamisele järgnenud karistustest. Mokornulgas on veel 2018. aasta sügisel kõneldud selle viimisest Krantsovasse: „Tuu Peko läts siist Ignasõ küläst kaoma. Ignasõlt läts ratsahobõstõga Krantśuvva. Krantśuvast edasi jälgi es lää’. Tuu kuju varastedi säält Ignasõlt aŕ. Täpselt ei tiiä keegi, kes või kuidas, a säält om lännu ta kaoma. Minu isä ütel', õt Jummal karistas neid mehi. Ja muidugi, neid, kelle peale ta arvati, ega nende elo hästi ei ole lännü, kedä rahvas mõtlõs. No mis sääl oll’ - kats perekonda, naa' omma' õnnetu' perekonna'. Häti pall’o olnu."”

Pekoga on seostatud ka 1967. aasta augustitormi, mis Härmält Ignasõ poole vaadates läks „nagu üks valge jutt üle põldude” ning hävitas täiesti Navigõ ja Ignasõ küla viljad. Tormikahjude niisugune jaotumine andis vanematele meestele taas põhjust kõnelda Pekost. Seda peeti Peko karistuseks Ignasõ ja Navigõ külale selle eest, et nad tema kuju lasksid ära varastada - juttude järgi Ignasõlt ratsahobustega Krantsovasse viidu.

Sattõ hirmsahe kõvastõ. Ja sis tulõmi, Andrikovalt tullimi tõsõ mehega kodo poolõ. Andrikovah oll' tõstnu mehe üles tuul, nii kõva pööristorm oll'. Ja üte uibo vei aŕ üts katskend meetrit kavvõndõhe vai kolmkend, kõigõ juuriga võtt' vällä. Ma olõ uma silmäga nännü. Sääne torm. Ja tuu torm läts niiviisi, et mi küllä es putu', a Ignasõ ja Navigõ küläh tekk' puhta tüü. Kõik kartulipäälse' ja kõik pesś puru ja sis vilä lei maaha ja. [---] Ja sis ku ma tulli säält üts kilomeetri maad aŕ Andrikovast, sis sääl Krõusa pääl om ka talo. Sääl oll’ juba veid'kese purus tett', peedilehel mulgu' seeh ja. Tulõ ma Lindsi küllä timä läts uma küllä, ma lätsi edesi - Lindsi küläh mitte midägi! Härmä küläh ka absoluutselt mitte midägi! Nagu es olõki tormi olõmah! Ja mul esä oll’ sis karah siin, taah, ja ütel', õt joon tõmmati ette. Timä oll' karaga sääl tõsõh oroh, Ristioroh. Sis tä ütel', jah, õt, näet, jummal masś kätte tuu Peko vargusõ. (Haaviku Aksel, 2018*)

Samalaadne teade, küll vastupidises võtmes, on ka XX sajandi algusest. Kui 1906. aastal käis üle Setomaa suur rahehoog, jäid puutumata need külad, kus Pekot austati. Rahvas seletas pääsemist Peko abiga (Eisen 1908: 378). Karistuse järgnemisest Peko müümisele on kõneldud ka Tal'kas: „Peko oll Ignasõ küläh. Säält viidi aŕ, müüdi Soome. Sis vana' inemise' kõnõli', õt karistus tulõ. Midägi oll' tulnu kah. Midägi peläti, pikset vai põuda, õt midagi juhtu vai..." (Valgna Vasśo, u 70 a, 1993*). Ka Otsa talu rehe põlemises on nähtud seost jumala kadumisega: „Ku Peko aŕ varastadi vai anti - täpselt ei mälehtä - lõi pikne Otsa talu rehe palama""10 (Sillaotsa Liidi, 1996*).

${ }^{9}$ Jutt varastatud Peko kuju Krantsovasse viimisest võib olla lahti lastud jälgede segamiseks, et luua seost Ignasõ Peko kadumise ja Krantsova Peko muuseumile mahamüümise vahel. Viimane juhtum sai Setomaal laiemalt teatavaks.

${ }^{10}$ Jutus segunevad kaks eri sündmust: tegelikult lõi pikne põlema Ignasõl Tõnise talu rehe mitu aastat pärast tulekahju Otsa pool (Ignasõ, Leoste Paul, 2018*). 


\subsection{Jumala varjamine}

Kuigi juba enne sõda levisid jutud kuju varastamisest, viitavad mitmed asjaolud sellele, et tegelikult jäi Ignasõ Peko Otsa Petra kätte. Kuju on tema uues elamises Navigõl näinud mitmed. Seal on Petra aidas viljasalves luku taga olevat kuju näha saanud Ermakovast pärit Heino Keskküla, kellele seda peremehe äraolekul salamisi näitas 5. või 6. klassis kooliõest sõbranna, Petra sugulane. Kuju oli 50-60 cm pikkune ja umbes $15 \mathrm{~cm}$ läbimõõduga. Tumedaks tõmbunud puu oli küünlavahaga koos. Puujumala pea oli sama jäme kui keha ja tasase pealaega. Kujul olid sisselõigatud silmad ja kaelakoht, kaelas oli midagi õlgedest tehtut. Peko oli vilja sees pikali, kaetud umbes $10 \mathrm{~cm}$ paksuse terade kihiga, ja sõbranna tõmbas käega vilja pealt ära: „Kae, et sa ei ütle kellelegi!" (Heino Keskküla, 2016-2018*)

Kuju oli oma hoidja jaoks tähtis ka pärast avalikkuse eest varjule viimist. 1950. aastate lõpus koges juhuslik pealtnägija Navigõl, kuidas Otsa Petra, ise kuuvalgel põlvili, palub aia peale tõstetud Peko kuju poole. Mees keeras värava peal otsa ringi ja tuli tagasi. Sarnane juhtum oli sama küla elaniku teatel veel 1977. aasta paiku: üks nende sugulasi oli õhtul läinud Otsa tallu tüdrukuid otsima. Naised olid saunas, aga vana Petra just saunast tulnud. Peko kuju oli pandud aia peale, aiasaiba otsa, ja Petra oli kuupaistel põlvili maas, ülakeha paljas. Käed ees kokku panduna üles tõstetud, palus vana mees vana jumala poole. (Navigõ, 1996*)

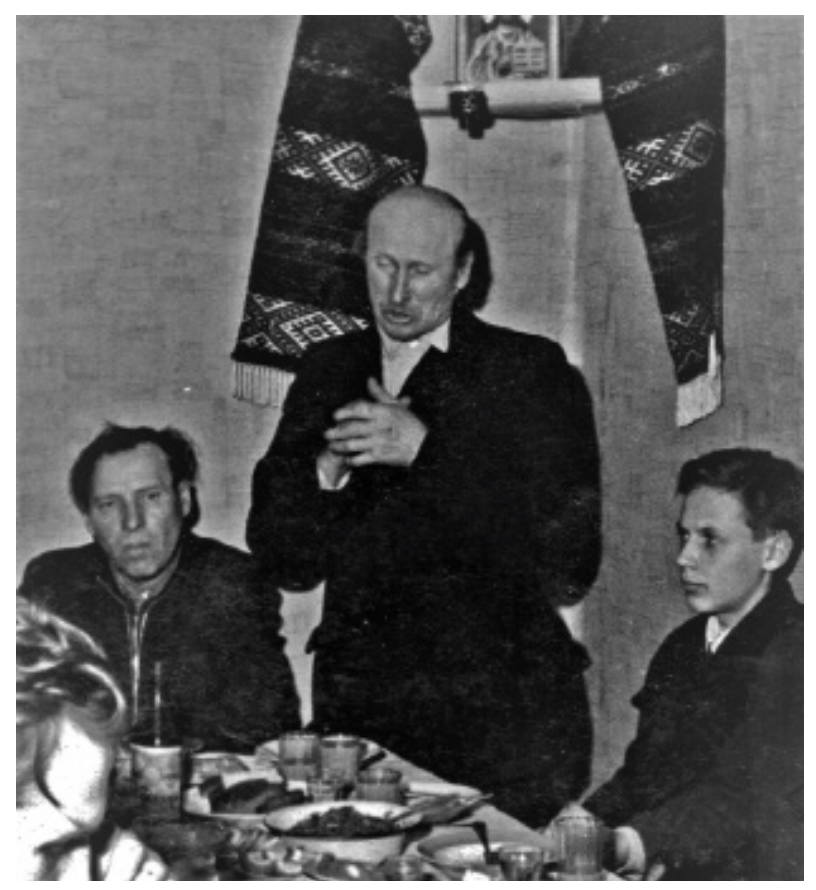

Illustratsioon 1. Otsa Petra 1960. aastate algupoolel pühäsenurga ees palvet lugemas. Foto: erakogu. 
Mis mees oli Setomaa viimane Peko peremees Otsa Petra? Obinitsa ümbruses kogutud mälestuskildude põhjal kujuneb järgmine pilt. Peeter Peetri poeg Ots $^{11}$ (1900-1980) (ill 1), tuntud ka kui Otsa Petra, Piitre, Petja või Pets, sündis Ignasõ külas. Pärast isa surma elas ta koos ema Maria ehk Maaŕa (snd 1868 või 1869), noorema venna Nikita ehk Miki (1908-1988) ja vennanaisega talus, kus jätkuvalt peeti Peko teenistusi. Seda, et talu on olnud Pekoga seotud mitu põlve, kajastab Obinitsa lähistel Petra kohta käinud ütlus „esä oll’ ka papp”.12 1953. aastal on Navigõl samas seoses mainitud ka Petra ema: „Otsa imä oll’ peko pidaja” (EKM ERA, RKM II 44, 509 - Navige k, Udo Mägi < Anna Kuusik (1953)).

Vanade kommete pidamisega Otsa Petra silma ei paistnud: „tavaline inemine oll'" (Valk 1999: 155). Petra oli Navigõ kooli kooliteenija. Eelkõige mäletatakse teda kui kirikumeest. Nagu märgitud, oli Petra Obinitsas „kirikuteener" juba 1944. aastal. Preestri abiline, kerigovanõmb ehk puul pappi oli ta ka 1950. aastatel pärast Obinitsa uue kiriku valmimist aastal 1952 (Härmä, Haaviku Aksel, 2018*), aidates preester Filimon Talomehel teenistusi läbi viia. Kirikuvanem korjas raha, osales lahkunute mälestamisega seotud kutjalaua ${ }^{13}$ seadmisel, aitas preestrit matuste ajal ja oli peielauas meieisapalve eestütleja, kui preestrit kohal ei olnud. Petrat on Kõõrul meenutatud kui küünlamüüjat, aga ka kui küünalde tegijat: „noh, kes neid vahaküünlid tegi vai [---], näet, tuu, vist tuu kerigumiis oll’” (EKM ERA, FAM 103 (31), 1994). Paasapäeva ja pühade ajal toimetas Petra ka surnuaial - teda kutsuti matuste peale, st haudadele pominaaljaid ${ }^{14}$ lugema: „havva pääle lätt’ ja laul’”. Petra läks kirikusse igal pühapäeval (Ignasõ, Leoste Paul, 2018*). Naabrinaise Maria Pihlaku ehk Pihlagu Manni (1925-2018) sõnul käis ta pühade ajal kirikus Taeluvas ja suurte pühade ajal Petseris (Navigõ, 2016*). Kirikumehena mäletab Petrat ka lauluema Linnupuu Anne.

Ma Otsa Petrat viil mälehtä, ku tä Navigõh oll’' Tä käve kerigohe, tä oll’ nigu kerigo vanõmb vai, midägi kerigoh oll', nii avit' preestrit, tuud ma mälehtä. Kõgõ nii ku läts armulavvalõ, sis pallól’ nii ku rahva käest, õt „andgõ’ mullõ andist!" [---] Mul om meeleh, õt panni käe' kokko: õt andgõ' mullõ andist! [---] Tuud om meeleh latsõl, õt rahva käest küsse nii andist. Ja rahvast sis olli. Nii ku kõnõldi, õt eś tekk' pattu ja sis rahva käest küsse andist, ku armulavvalõ läts. [---] $\left(2017^{*}\right)$

Erinevalt teistest Ignasõ taludest oli Petra hoonete ustel silmapaistvalt palju söega tehtud riste ${ }^{15}$ - kellelgi külas ei olnud neid nii palju. Maria Pihlaku sõnul (2016*) tegi naaber alati kolm ristimärki, sest „Petra oll’ ju kerigumiis”.

${ }^{11} \mathrm{Nii}$ isa kui ka poja tegelik ristinimi oli õigeusu nimetraditsiooni kohaselt Pjotr, vt ka RA, EAA.5433.1.7, 1128.

12 Tundmatu 60-65 a vanune mees Heino Keskkülale 2018. aastal.

${ }^{13}$ Kutjalaud - kirikus olev laud, millele lahkunud sugulaste mälestamiseks pannakse väike anum rituaalse toidu, kutjaga, mis vanemas traditsioonis tehti hernestest ja meest.

${ }^{14}$ Haual surnutele lauldav mälestuspalve õigeusu traditsioonis.

${ }^{15}$ Seto, nagu ka laiemas rahvapärase õigeusu traditsioonis kaitsevad viirist'mise päeval (19. jaanuaril) ustele ja akendele tehtud ristid maja tuleva aasta vältel kurja eest. 
Navigõl ja ümbruskonnas peeti Petrast lugu. Külavanema Rein Tarrose sõnul (Navigõ, 2017*) anti vanale mehele nende juures külas olles kõige parem ja soojem koht - Petra istus ikka ahju- või pliidisuu ees pingikesel tule paistel ja teised mehed kuulasid, kui ta kõneles. Petra sai naabritega hästi läbi, kuid ei armastanud külalisi ega tahtnud, et tema pool käiakse. Oma maja kõrval olevast kooli võrkpalliplatsistki püüdis ta poisse eemale hoida: võttis võrku maha ja mässis võrgupostid okastraadiga, et poisid nende otsa ei roniks.

Petra on maetud Obinitsa kalmistule, tema haual on lihtne enda tehtud kadakane rist. Pärast Petra surma olevat Pekot tema pool otsimas käidud. See leitud vana tare pealt väikesest punutud karbist, milles hoitud kirikuküünlaid. Olnud vahast, ilusti ära pakitud, aga täiesti ära pudenenud, nii et ei saanud arugi, missugune ta õieti oli. (Navigõ, 1996*) Ka ühes varasemas teates on Ignasõ Pekot kirjeldatud kui vahatükki: „Peko ise ei ole muud kui rusika suurune vahatükk” (EKM ERA, ERA II 247, 487 (9) < Ignase k - Aleksander Lill < Marie Ots, 70 a (1939)). Need kirjeldused ei sobi kuidagi puust Peko kujuga, mida on lisaks Heino Keskkülale Petra talus näinud ka Ilmar Vananurm (snd 1946) veel 1982. aasta paiku. Tema mälestuste kohaselt oli see aidas, hööveldamata laudadest riiulil. Kuju olnud 40-50 sentimeetri pikkune, pealagi küünlarasvaga koos (2018*). Seega oli Petral Pekosid kodus mitu.

Petra juures olnud Peko puukuju saatus ja asukoht on teadmata, kuid selle kohta on ühetaolise sisuga arvamisi. Mitmed hilisemad jutuajamised on juhatanud tallu, kus juba 1994. aastal Meremäe valda tehtud seto usundipärimuse kogumisretkel anti Pekot puudutavatele küsimustele tõrjuvaid ja umbmääraseid vastuseid. Arutades Peko kujude saatust, tõdes Sillaotsa Liidi 1996. aastal, et „üts piäs olõma viil siinkandih”.

\section{Täiendusi puujumalate levikule Eesti kagunurgas}

\subsection{Küllätüvä Peko}

1993. aastal lisandus teadaolevate Pekoga seotud külade hulka Küllätüvä. Seal olnud Peko kujust jutustas mulle Uusvadas elanud Linnupuu Anne.

Sääl kandih om ka tuu Moklonulga Peko. [---] Kolja imä juures Küllätüväh oll’ viimati. Oll' nigu inemise kuju, puust, käeköndi' olliva' kah väikese', nigu ola kohal. Oll’ nii 70-80 sentimeetri kõrgunõ, nägu oll’ kah. No nüüd eläs tuu imä sääl ütsikult. Ku mi ollimi latsõ’, ollimi kõik sääl, mi tahtsimi kõik vanaimä poolõ. Ma olõ Küllätüväh üles kasunu. No sis sääl olõmi nännügi tuud Pekot Küllätüväh. Ja tuu sääl aida pääl oll’ ja ma mõtlõ tuud, et ei olõ’ kohegi viidü. Sis tull’ tuu sõjaaig pääle ja vaivalt et tä tedä inämb kohegi vei. (1993*)

Kuju oli Anne vanavanemate pool Rikka-Ivvani talu aida pööningul: tarapäälise üks nurk oli puhas ja kuju seisis seal püsti. Anne mälestustes olnud Pekol kahele poole välja nikerdatud juuksed, küünlaid pea peal ei olnud. Lühikesed käed („säändse' nutikese”) olid välja raiutud samast puupakust, rinnal kõrvuti või vaheliti. Ümaral alusel kuju suurust on Anne hinnanud umbes 
meetri pikkuseks. See Peko olevat tehtud Lindsi ja Ignasõ kandi Peko järgi ning eeskuju olnud vahast. (2005*)

Anne ema Maria Luuga ehk Luuga Manni (1908-1992), sündinud RikkaIvvani talus, oli talule nime andnud legendaarse vanaperemehe (1850-1911) pojatütar. ${ }^{16}$ Anne mäletab, et ema käis Pekot hobusega toomas.

Tuu jaost tälle tuudigi, et õnne tuu. Kui tundse, et elu ei lähe, sis võtsi tä. Nii et tuu oll’ nigu inemistel tiidä', et kos kottal timä om. Tedä aasta jooksul tiiät mitu kõrda viidi kohe. Hobõsõga viidi. Mu imä om tedä toonu ütest talost tõistõ ja kelle puul sis vaja oll’. Kui sis näütest sinnä Küllätüvä tallu, kui looma' sünnit'. Imägi om ütelnü, et ma olõ toonu Obinitsast ja kelle puult sis. Et juhatati, et kelle puul taloh om tuu Peko. [---] Et tuudi Pekot, et ahah, nüüd looma' ei lää' ja kõik om viltu, ja mindi ja tuudi tuu Peko. Puukuju. (1993*)

Pekot transportis vajadusel ka Anne vanaema, keda tunti ravijana. Koos Pekoga läks hädalisse tallu peotäis jumala juurest võetud aganaid, mida söödeti loomadele. Anne sõnul viidi Pekot vaeste juurde või vaesusest lahti saamiseks: „Kui olli’ vaesema inimese, vanaesä vei sinna, tuudi Küllätüvvä tagasi. Tõnõ talo sai ka rikkambast." Loomahädade puhul tuldi Peko juurde paluma. $\left(2005^{*}\right)$

Anne vanavanemad pidasid Pekot pühaste ehk ikoonidega samavõrd pühaks: „Peko oll’ niisama pühä ku jumala' olli””. Kuju tarre ei toodud, kuid pühade ajal viidi Pekole sööki: munadepühal muna, paasapäeval õunu ning midagi ka talsipüha ajal. Kui vanavanemad Peko juurde läksid, siis „sinna latsi mano es lasta; sis pessti latsõ minemä, ku Peko juurde mindi”. Siiski käisid lapsed tihti salaja Pekoga mängimas - olid isegi kuju seljas ratsutanud ja hobust mänginud. Pekoga mängiti ka peitust, peites teda aganate sisse. Ajal, kui kuju vahel talust ära oli viidud, oli lastel igav. Kui vanaisa, Rikka-Ivvani poeg Lillepuu Miko (1876-1938) toimunust teada sai, tuli väga suur pahandus: „Saimi tükk aigu olla' näoga saina poolõ ja saimi nii, õt perse' olli' triibulise”". Vanaema Anne käest tuli tolle aja kõige suurem karistus: „Lavva taha es lasta! Ma olli’ päiv otsa süümäta!” Arvestades asjaosaliste eluaastaid, pidi episood vanaisaga toimuma 1935. ja 1938. aasta vahel. (2005*)

Peko kuju oli Küllätüväs Rikka-Ivvani talus veel 1993. aastal. Kui Küllätüvä Peko Uusvada külas Linnupuu Anne pool jutuks tuli, arvas Anne poja Raivo Linnupuu (1961-1994) sõber ja sugulane Kolja (1938-2010), et see võiks vanatare $^{17}$ peal alles olla, ja lubas näha tuua. Kuid pärast kohtumist oma emaga (1912-1999), kes vanaduspäevil talus üksinda elas, oli sõnum selge: kuju ei ole enam alles! Raivo kommenteeris asja järgmiselt: „Äkki taha-i jummalat imä aŕ anda'? Äkki vat omgi, õt annat kuju majast aŕ, õt tule määnegi pahandus majja?” Et kuju toona tegelikult talus olemas oli, kinnitas mõni päev hiljem ka Anne: „Ma täna Manni käest küsüse. Manni ütel’: „Om jah sääl!”” $\left(1993^{*}\right)$

${ }^{16}$ Rikka-Ivvani suguvõsa liikmete eluaastate andmed kuni 1980. aastateni pärinevad Raivo Remmeli koostatud suguvõsa kroonikast (1982) ja nimekirjast (1988).

${ }^{17}$ Rikka-Ivvani talu on kahe „otsa” ja nende vahel oleva seenisega. Maja vanem, Ivvani ehitatud osa on teest kaugemale jääv vanatare. 
Küllätüvä Peko saatus on teadmata. Kui talu 2002. aastal uutele omanikele müüdi, oli laguneva vanatare pealne asjadest tühi. Kuju seal enam ei olnud.

\subsection{Uusvada Peko}

Lisaks Eesti Rahva Muueumis olevale Krantsova külast pärit kujule on alles teinegi Peko, Uusvada külast (ill 2). Selle Obinitsa muuseumis asuva kuju andis 2000. aastate keskpaiku muuseumi rajaja Liidia Sillaotsa kätte laulumees ja Uusvada ajaloo uurija Vahelaane Paul (snd 1936). Kuju, mis seisis Vahelaante aida peal linasesse riidesse mässituna, on puust treitud ja mustaks värvitud, $39 \mathrm{~cm}$ kõrgune. Peko jalaosa on astmeliselt laienev. Piklikku pead, millesse on lõigatud kriipsukestest silmad, nina ja suu ning kaks pisikest kõrva, ümbritseb otsmiku kõrgusel kitsas rant. Pea peal kübarataolises treitud laiendis on 11 auku küünalde jaoks. Kuju $15 \mathrm{~cm}$ läbimõõduga põhja alla on lõigatud Rooma numbreid meenutavad märgid. Selle kuju tegi annetaja vanaisa, tisler ja meistrimees Vahelaane Jakob ehk Jaagov (1885-1945) XX sajandi alguses. Uusvadas, kus Peko kohta öeldud Mokorluga püha (Vahelaan [2004]: 68), Pauli sõnul Pekot ei peetud: „See Peko jant oli sääl Obinitsa pool” (2016*) ja isa suhtumine kujusse oli halvustav: „Isa ütles ikka „Ah, see Peko! Meie oleme ikka ristiinimesed!"' (1993*)
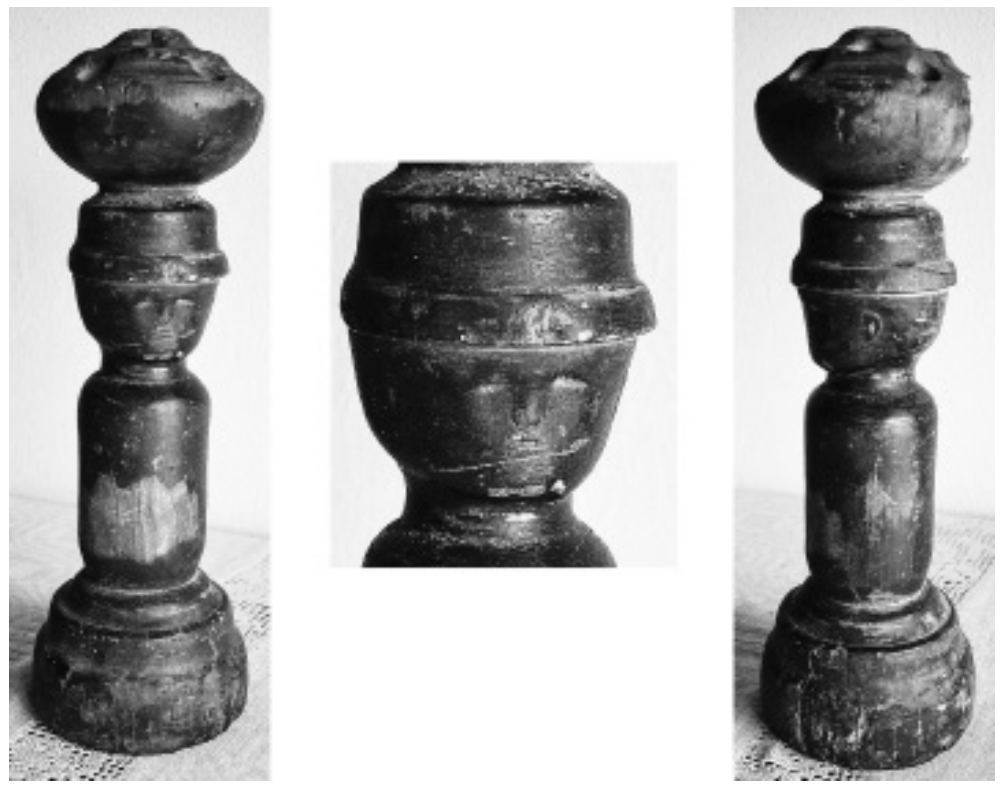

Illustratsio on 2. Uusvada külas treitud Peko kuju Obinitsa muuseumis (OSM P166). Vasakpoolsel fotol eestvaade (keskel suurendatud nägu), parempoolsel fotol külgvaade. Fotod: Heiki Valk (2018). 


\subsection{Puujumal Ermakova külas}

Puust jumalakuju on olnud ka Üle-Pelska nulka kuuluvas Ermakova külas, nõiaks peetud Akulina Mägi ehk Timmoś Kull’o valdustes. Teadmine sellest on säilinud Keskküla Heino mälestustes (2006-2018*), kes on kuju väiksena ligemalt näinud Kull'o aidas, kus see oli poolka, st riiuli peal külili. Riiuleid oli aidas kaks-kolm, neil seisid savist potid. Mustaks tõmbunud, 40-50 cm pikkune lehtpuust kuju, mida külas kutsuti puujummal või puusligutükk, oli tehtud ümarast, ligi $15 \mathrm{~cm}$ jämedusest, alt sirgelt lõigatud pakust. Kujul oli kaelakoht („tsälk oll’ sisse lõigatu”) ja jalad olid nii esi- kui ka tagakülje alaosas markeeritud 8-10 cm pikkuse sisselõikega (ill 3). Ülaosas, justkui tahutult kandilise, pealt tasase pea lael olid augud, vist küünalde jaoks. Piklikud silmad, mis tundusid olevat mustaga värvitud, ja väike $3-4 \mathrm{~cm}$ pikkune suu olid noaga sisse lõigatud, nina ei olnud. Kuju pea ümber oli midagi linast või takust paklaste juuste taolist ning ümber oli pandud justkui riidehilp ja midagi õlgedest: „Olist oll’ täl..., olõ' olli’ nigu' ümbre pantu'... Esä mullõ ütel’: „A tuul Kull’ol om tuu kurradi puuslik sääl jah!” Üteldi, õt „Kurrat, Kull’o pallõs sääl puujummalat!"” Kui Heino aidas lähedalt nähtud kujust kodus kõneles, tekitas see vanemates huvi: „Mine' kae' viil!” Heino märkmetes leidub 1958. aasta paiku tehtud ülestähendus vestlusest Kull'o venna Hilipiga (Filipp): „Hilip ütel': Kull'ol om uma puust Peko, taga nukah sängü man. Timä hoid tedä talviti sääl. Timäl om taa sääl jo kavva aigu.” - [Heino:] „Kus ta on?” - „Vot seda ma ei tiiä, kos täl tä praegust om." (2019*)

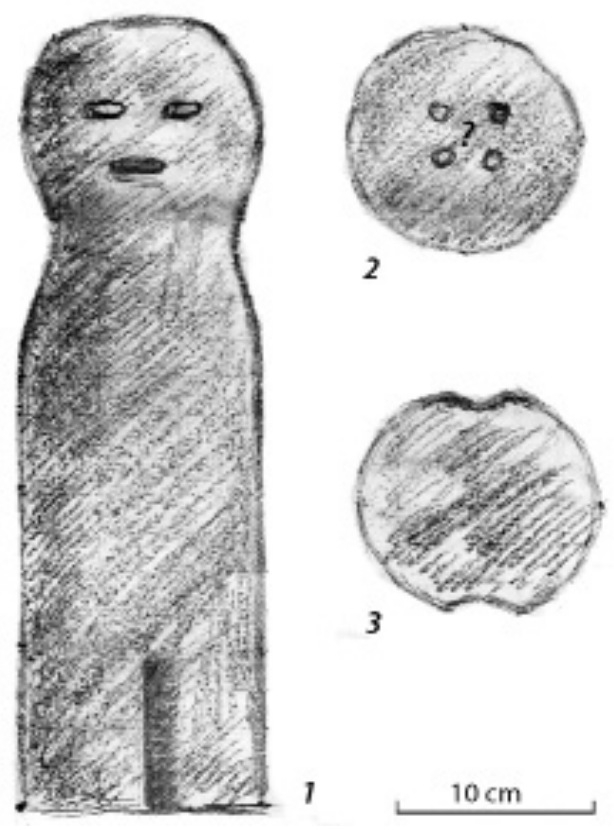

Ill u strats i o on 3. Peko kuju Ermakova külast. 1 - eest, 2 - pealt (küünlaaukude täpne arv pole teada), 3 - alt. Umbes samasugune, kuid veidi enam töödeldud, oli ka Ignasõ Peko. Joonise alus: Heino Keskküla; teostus: Heiki Valk, Jaana Ratas. 
Kevadise karjalaskmise ajal läks Kull’o, valge põll ees, küla taha Paasńamäele, kus oli nende talu karjamaa. Heino mälestustes oli naise käes noorte lehtedega viht, millega ta karjateele enda ette vett piserdas, vanem vend Hilip kõndis musta lehmaga taga: „Mäletan, kui ta tamme juurest ajas neid loomi alla Paasńasse. Pang oli käes, põll oli alt üles keeratud, too [kuju] oli sääl sees, vihaga viskas veel vett. Isa ütles ikka: „Näe, jälle see Kull’o oma puuslikuga!'” Vesi oli võetud külas olevast Silmälättest, mida kutsuti ka Nõiakaiv ja mille juures Kull’o tihti toimetas. Vee kohta üteldi timä [st Kull'o] ristivesi. Algul kastis naine külast karjateele viiva värava juures viha vette ja pritsis kahele poole, karjamaale minekul tegi ta sama, nagu lehma tee puhastamiseks, ning siis, pang ja viht käes, „lõpetas ära selle ringi”. Enne puuslikuga ringile minekut toimetas Kull'o tükk aega aidas. Mida ta seal tegi, ei ole teada.

Kull'o noorema venna Höödori (Fjodori) naine Hökla (Fjokla), pärit Petseri tagant Trubalt, nimetas kuju Heino mäletamise järgi Mokolnuka Peko. Samas pole teada, kas ütlus viitab kuju päritolule sellest piirkonnast, sest kuigi kohalike jaoks oli Mokolnuka idapiiriks laia oruga Tuhkvitsa oja, kutsusid Petseritagused setod Heino teatel ka Pelska oja ja Tuhkvitsa oja vahele jäävat ÜlePelska nulka Mokolnukaks.

Lisaks oli Kull’o aidas teinegi kuju. Seda nägi Heino viie- või kuueaastase poisikesena 1950. aasta paiku, kui naine aidas võid tegi: kollane õlgedest ja näota nukutaoline kuju (vt mälupõhist jäljendust ill 4) hakkas üle ukse sisse vaadates seinal kuivavate ravimtaimede vahel kohe silma: „[---] rippus vasakul pool. Seina peal rippus, õlgedest tehtud, 40-50 sentimeetrit pikk. Nagu

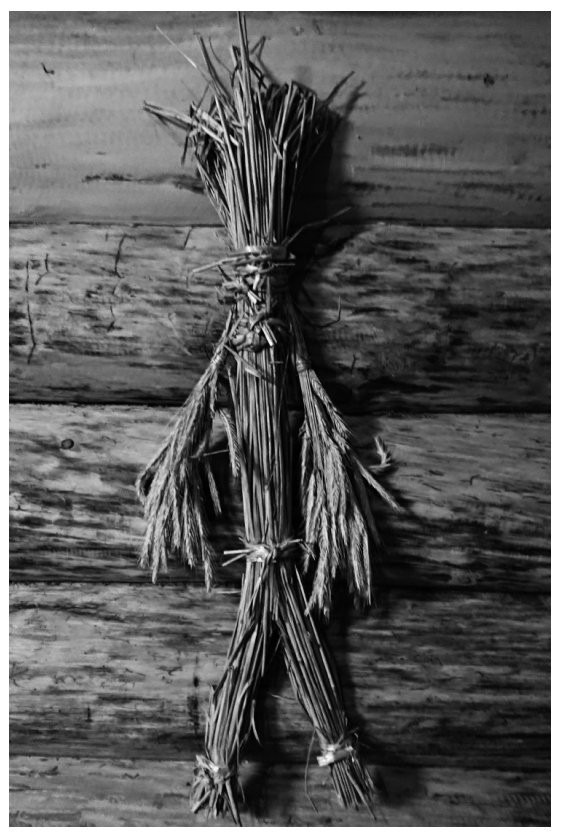

Ill ustratsi o on 4. Viimastest rukkikõrtest kuju, millist Ermakova Kull’o karja väljalaskmisel kasutas. Heino Keskküla rekonstruktsioon mälestuste põhjal. Foto: Eve Ellermäe (2018). 
pea oli jämedam, õlgedega oli kokku seotud. Kaks jalga oli all ja kaks kätt oli, pea oli otsas [---]." Lehma karjamaale viimisel oli see kuju vanapoisist venna Hilipi käes, kes looma talutas. Kull’o aida kohta lisab Heino: „Osadel oli aidas ikoon, minu vanaesäl ka. Temal sellist asja ei olnud. Ta mitte kedagi ei lasknud sinna aita, kui ta sealpool kamandas. Mina, naabripoiss, vahel sain vaadata. Sinna aita es saa keski pääle mu - selle, õt ma sai Kull'oga hästi läbi.”

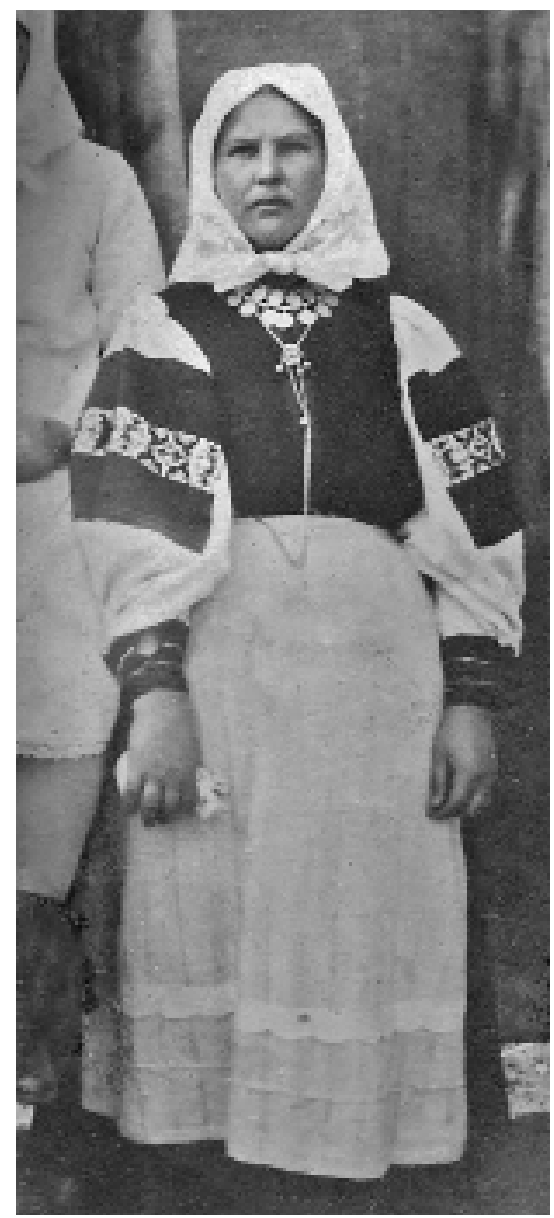

Illustratsio on 5. Akulina Mägi (Kull'o) 1930. või 1940. aastatel. Foto: Tõnu Suuvere perekonnaalbum.

Ignasõlt pärit Jefimia Masti ehk Masti Hemmo (1900-1983) jutu ja Liidia Sillaotsa vahenduse kohaselt oli pekosid kahte liiki: lisaks külapekole tunti ka maja- ehk talupekot, viimastest põllult korjatud õlekõrtest nukku, mida „hoiti nagu vilja kaitset (Peko andi) järgmise külvini” (Sillaots 2008: 80). Ehk on aidas nähtud kuju just selline abiline? Seost aitavad luua Heino isa sõnad: „Egä sügüse tekk' tä vahtsõ." Õlgedest nukk, millega seotud riituste eheduses pole põhjust kahelda, kuulub puujumalaga võrreldes siiski hoopis teise 
traditsioonideringi. Õhku jääb küsimus, kas niisugune pekode klassifikatsioon pärineb tõepoolest Masti Hemmolt või on tegemist haridust ja teadmisi väärtustanud teeneka kodu-uurija omapoolse sõnakasutusega. Küla-, maja- ja talupeko nimetust pole varasematest arhiivimaterjalidest õnnestunud leida ning ka inimeste küsitlemine pole andnud tulemusi.

Akulina Mägi sündis XIX ja XX sajandi vahetuse paiku ühes kolmest Ermakova küla talust. Mehele Kull'o ei läinud, arvatavasti oli põhjuseks tüdrukuna saadud laps. Täiskasvanueas (ill 5) hoidis Kull'o omaette, paabapraasnikutel ega naistega laulmas ei käinud, ka ei tarvitanud ta tilkagi alkoholi. Olemiselt oli hästi kodune, „elus võib-olla kaks-kolm korda käis Petseris”. Kull’o kandis alati seto rõivaid: tavaliselt oli tal seljas linane kirjadeta särk ja tumedam (hall või must) kitasnik ${ }^{18}$; alati oli peas valge rätik. Pärast vanemate surma jäi Kull'o talu pidama koos kahe vennaga, olles seal nii perenaiseks kui ka peremeheks. (Heino Keskküla, 2018*)

Perepärimuse kohaselt, mida vahendas Akulina Mägi lapselapselaps Tõnu Suuvere, oli Kull'o ravitseja, kes võis ka tulevikku ette näha. Tema juurde käidi üle terve Setomaa ja isegi Pihkvast. Võimed oli ta pärinud emalt, kelle kohta üteldi külas posija. Midagi oskustest pärandus ka tütrele, kes neid aga ei kasutanud. Tääglüväst pärit Olga Juusi (snd 1928) sõnul ravis Kull'o sõnadega (arvatavasti ka taimedega) käe- ja jalavalusid, üleüldse ütles ta kõike „Sõnadega”, st laulurütmis. Rahva hinnangul oli Kull’oga kasulik hästi läbi saada või siis üldse mitte läbi käia; halvasti läbi saamisest tuli hoiduda, et mitte ära nõiutud saada. Naine suri 1960. aasta paiku ja on maetud Taeluvasse.

Mägide pere oli eraklik, inimesed paistsid silma vanade kommete poolest ja pole teada, et nad oleksid kirikus käinud. Naise ja ta vendade majast ei mäleta Heino pühaseid, kuid toa nurgas oli samasugune lamp, nagu rippus ikoonide ees. Kui Kull'o vend Höödor Petseri tagant Trubalt naise võttis, tekkis peres konflikt, sest uus pereliige „oll’ tõist usku”. Noorpaar asus elama omaette: alguses sauna, pärast Höödori ehitatud majja, kus oli pühasenurk. Kull'o kohta üteldi Heino mälestuste kohaselt külas: „Tä om tõistmuudu inemine ku mi'. Täl om uma jummal.”

\subsection{Puukuju Tupl’́uva külas}

Tartu Ülikooli üliõpilase Diana Illaku (snd 1997) ebamääraste lapsepõlvemälestuste kohaselt oli Peko-laadne puust kuju veel 2000. aastate alguses ka Tupl'uva külas. Vanaisa talu aidas nähtud kuju olnud kulunud ja „puupaku suurune", 40-50 cm pikkune. Teadmine, et tegemist võiks olla Pekoga, tuli alles Obinitsas koolis käies. Praegu kuju, millel olnud ümmargused silmad ja mis viimati olnud pistetud aida räästa alla, enam alles ei ole (2019*), see võis kaotsi minna viimase remondi käigus. 1951.-1952. aasta paiku on Tupl'uvas Vana-Illaku ehk Illaku Petra talu (see oli küla vanim majapidamine) kohta üteldud: „Naa' ei olõ' ristiinemise', naa' palssiva puujummalit” (Laane Leo Heino Keskkülale).

\footnotetext{
${ }^{18}$ Seto naiste puuvillasest riidest argipäevane pihikseelik.
} 


\subsection{Mokornulgast kaugemal: Krantsova, Saabolda, Lüütsepä ja Palli}

Peko kultuse senistel levikukaartidel (Ränk 1934: 193, joonis 5; vt ka Hagu 1997: 41; Västrik 2017: 520, joonis 5) asub Eesti Rahva Muuseumisse jõudnud Peko koduküla Krantsova üsna üksinda: Mokornulga lähimad külad jäävad enam kui 7 km kaugusele. Luhamaa nulgani, kus Pekot Jüri Truusmanni teatel austati (Truusmann 1890: 38), ent kust pärit hilisemate teadete autentsus on Paul Hagu hinnangul (1997: 37) küsitav, on otsejoones ligi $5 \mathrm{~km}$. Siiski muudab Krantsova staatust Peko kultuse levikukaardil teade, et halbade sügisilmade korral, kui viljasaak ähvardas vihmaga hävida, on Krantsovast vanasti Peko kuju toomas käidud (Meremäe, 2018*). Seda rääkis Meremäe raamatukogu juhatajale Anni Lahele tema onunaine Vahviku Tepa (18931978). Jääb selguseta, kas kuju viidi $3 \mathrm{~km}$ kaugusele Palo külla, kus jutuajamine vilja hukutavate sügisvihmade ajal 1960. aastate keskpaiku toimus, või $5 \mathrm{~km}$ kaugusele Poksale, kust Tepa mehele toodi.

Saatse lähedal Samarinnas suviti elanud skulptori Renaldo Veeberi (1937-2010) loomingus on Setomaa teema tähtsal kohal (Veeber 2014). Aastatel 1990-2009 tegi kunstnik rohkesti puust Pekosid, milleks andis alust 1978. aasta paiku Saatse lähedalt Saaboldast ühe väikese vana maja pööningult leitud kuju. See olnud kasepuust, ligi $60 \mathrm{~cm}$ pikkune, puukoidest täiesti ära söödud ja poolenisti tolmuks pehastunud. Kuju oli ümara peaga, näos silmad, nina ja suu, pealae keskel auk küünla panekuks, vastu külgi käed olid kolme sõrmega. Sarnaselt Krantsova Pekoga oli sellel jõulukuuse jala taoline ristikujuline alus. Nimetatud kuju järgi on tehtud Saatse muuseumis olev Peko - samasugune, kuid ligi kaks korda suurem (Samarinna, Renaldo Veeber, 1993*). Ajakirjas Peko Helü kirjeldab Veeber kuju leidmist järgnevalt: „[---] lõüdse [---] puuroika, koh olliva ${ }^{q}$ mulgu $^{q}$ nigu silma ${ }^{q}$ ni tuu roigas oll' väega prostalt kirvega tett'." Kui skulptor nädala pärast tagasi läks, et kuju ära tuua, oli hurtsik maha põlenud (Riitsaar 2006: 17).
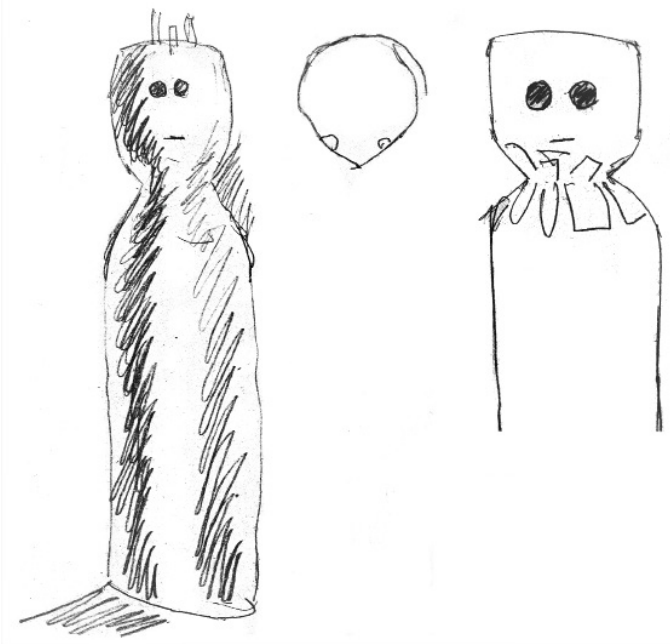

Illustratsioon 6. Puust jumalakuju Rõuge kihelkonnas Rogosi lähedal Lüütsepä talus. Joonis: Renaldo Veeber (1993), töötlus Jaana Ratas. 
Kuigi Peko kultust on Eesti piires seni seostatud Setomaaga, on puujumalat tuntud ka Rõuge kihelkonnas. Teise kuju on Renaldo Veeber leidnud oma vanaisa Karla Pettäi kodust Rogosi ehk Ruusmäe lähedalt Lüütsepält: praegu Tammemäe nime kandva talu aidas seisnud kuju olnud umbes $65 \mathrm{~cm}$ pikkune lihtne männipuust pakk, millesse oli kirvega tahutud kaelaosa. Kuju silmad asunud ligistikku, suu oli väike ja „nägu kuidagi soome-ugri pärane” (laiade põsesarnadega). Pealaele oli puuritud kolm auku, kus seisid küünlad (ill 6), jalga kuju all polnud. See olnud kunstniku sõnade kohaselt „perekonna heaolu jumal”. Kui vanaisa 1964. aasta paiku suri, kadus aidast ka kuju (Samarinna, Renaldo Veeber, 1993*). Vanaisa oli pärit Haanjamaalt Peipsi taha Katseeritsa külla välja rännanud perest ja Saksa ajal Eestisse naasnud, Lüütsepäle elama sattunud oli ta vist juhuslikult, talusse tulnud töömehena (teated vanaisast Renaldo vennalt Vitali Veeberilt, 2018*). Seoseid Setomaaga ei tea sugulased tal olevat. Pole teada, kas kuju oli pärit Lüütsepält või oli see Peipsi taha kaasa võetud ja sealt tagasi toodud.

Teade Lüütsepä puujumalast ei ole Rõuge kihelkonnas ainuke. Peka (ja mitte Peko) nimelisest jumalast tuli Palli külas kohapärimuse kogumisel juttu veel 1999. aastal. Tegemist ei olnud n-ö välja küsitud vastusega. Kui vestlus oli viidud vanade asjade ja aegade meenutamise lainele, võttis teema üles küsitletav ise:

- Meil oli jo sääl, eesots vat... oli puupakk raiutud, inimese pää otsas, see oli Peka, see oli aganate sees. Selline vana Eesti põlvkondlik jumal, Peka.

- Peko, jah?

- Jajah, see oli aganate sees, aganates.

- Kus siin seda Pekat veel austati, kas siinpool ka või?

- Meil oli ka siin, aida otsas, aganate sees, ku ma poisikene olin. Koer käis ikka sinna magama.

- Mis aastal see siis veel oli?

- Tuu oli no kahe-, kahekümne kuuendal-seitsmendal vai..., oi, hiljem, kahekümne kaheksas, kahekümne üheksas.

- Sel ajal Pekot austatud siin veel!?

- [Naeruga] Peka ikka. See puust raiutud pakk, ta oli vanaisa-aegne, viil vanaisa oma. Tuu oll' aganate sees.

EKM ERA, FAM 373 (38) < Kalev Koppel, Kristin Ilves < Rõuge khk, Palli k, Valdeko Leies, 74 a (1999)

Endises popsikohas elav Valdeko Leies (1924-2009) oli erakliku eluviisiga, kuid laia silmaringiga ja tundis saksa keelt. Talukohas praegu toimetava Leho Ainsaare teatel (2018*) oli Valdeko vanaisa nimi Karl Leies (1851-1926). Perekond ei olnud eriti usklik ega käinud kirikus. Sidemeid Setomaaga neil polnud, ümbruses elavad seto pered on asunud sinna alles pärast 1920. aastat. Valdeko Leiese õde Hilda (snd 1926) ei tea küll midagi puujumalast, kuid mäletab samuti 1930. aastate alguses aganikus magamas käinud musta koera - Peku-nimelist. Niisiis ei olnud Peko sõna (nimede variatsioonid on suulises kultuuris tavalised) Palli külas 1920. aastate lõpus tundmata ja koera magamiskoht puukuju juures ning must värv võisid loomale nime panekul kaasa rääkida. Teisalt oli Pekost 1920. aastateks juba mitmel pool kirjutatud ning 
see võis kuju nimetamist mõjutada. Väljend „vana Eesti põlvkondlik jumal” näitab hariduse ja lugemuse mõju jutustaja maailmapildile. Miks aga Peka ja mitte Peko?

Lisaks leidub Võrumaalt ebamääraseid mälestusi puukujust, mis olnud Varstu ja Krabi vahel asuvas teises Lüütsepä (nüüd Lüütsepa) külas, TaevaJaani aidakeses. Siinkohal tuleb nimetada ka Rõuge kihelkonnast Sännält pärit Juhan Jaigi (1899-1948) pikemat luuletust „Kesväesä” (1945), mis samuti kõneleb puujumalast: „[---] / Väitseotsaga tä tetti / Uibupuust, / Panti ümbre närtsu, rätti, / Pähä hiust. / Sügüse tä panti tünnist / Villäsalvõ, / Sääl tä siimneterri õnnist / Pika talvõ. / Keväjäl, ku külviterri / Nurmõ kanti, / Kesväesä pindreperve / Seisma panti / [---].” (Jaik 1999: 74) Sarnasus Pekoga on ühene, kuid pole teada, kust sai Jaik, kes oli Oskar Looritsa sõber, tõuke luuletuse loomiseks. Samas on kesväesä ehk kesväjummalakõsõ nime Haanjamaal mainitud teisteski seostes: Aigar Piho (Kiidi, 2019*) teatel seoses õlle tegemisega ja ka jummal sekka! ütlemisega saunaliste hulka minnes. Malle Vissel (Varstu, 2019*) mäletab, et kesväesä sõna tunti varem ka Varstu kandis ja samuti on see tuttav Valdur Tanilsoole Luutsnikult (2019*). Heino Keskküla on sõna kuulnud Ermakovas. Hellenurmes (Rõngu khk) tähendas kesväesä hirmutist, kolli või linnuhirmutist (hüljatud jumal on taandunud hirmuolendiks, vt järgmist peatükki), Raudojal (Vastseliina khk) ametimeest (vt FES). Asjaolu, et Võrumaalt on pooljuhuslikult teatavaks saanud nii palju puujumalatele viitavat, lubab arvata, et veel mõned põlvkonnad tagasi teati asjast märksa enam. Arvestades väga pistelisel küsitlemisel kogunenud pudemete hulka (kaart 1:5), võiks talletamata mälestuskilde leiduda siin-seal ehk veelgi.

Jumalakujude teema lõpetuseks tuleb tõdeda, et enamik kirjeldustest põhineb kaugetel, vahel ehk ka hägusatel lapsepõlvemälestustel. Tuleb arvestada, et lapseeas nähtu tundub sageli suuremana, kui see on päriselt. Seetõttu pole põhjust esitatud mõõtusid, ${ }^{19}$ detaile ega kirjeldusi võtta vääramatu tõena. Ülestähenduste tinglikkust kinnitab Lüütsepä puusliku kujutis (vt ill 6), mis on kahel korraga tehtud mälupõhisel joonisel - teine selleks, et pead suuremas mõõtkavas esitada - üsna erinev. ${ }^{20}$

\section{Tausta, mõtteid ja üldistusi}

\subsection{Peko ja ruum}

Kui jätta kõrvale idapoolsed soomeugrilased, võib Peko olla kogukondlikul tasandil kõige kauem järjepidevalt austatud ristiusueelse taustaga jumalus Euroopas. Sealjuures pole tegemist lihtsa kodu- või majavaimuga, vaid pikse, tormi ja rahe valitsejaga, kelle võimuses on viljasaak, karja edenemine, õnn ja üldine kordaminek. Peko kultus oli idapoolses läänemeresoome ruumis varem laiemalt tuntud ja selle elementidele võib vasteid leida ka kaugemalt ida poolt (vt ka Hagu 1975: 168-172; 1997: 39-40). Soome osas tuleb märkida Turu piiskopi Mikael Agricola poolt soome keelde tõlgitud ja 1551. aastal ilmunud Taa-

${ }^{19}$ Kujude pikkuse väljendamine sentimeetrites on enamasti küsitleja algatus: sageli näidati seda käte abil.

${ }^{20}$ Lähivaates lühema pea põhjustas joonistamisruumi piiranud perfokaardi serv. 
veti psaltri luulelises eessõnas leiduvat Karjala ebajumalate loendit, milles Pellonpecko ehk põllupeko on odrakasvu andja: „Pellonpecko / Ohran casuon soi” (Agricola 1987: 212). Karjala ja Soome pärimuses jumala nimi varieerub, kusjuures Pellonpekko või Pellonpekka seostub mitte üksnes odra- või viljakasvuga, vaid ka õllega (Harva 1948: 190-191; Haavio 1959: 118-121). IdaSoomes on pellon Pekka tähendanud nii põlluhaldjat kui ka lastehirmutist (Harva 1948: 192).

Pellon pekka (või pekko) esineb ka Karjalas ja Savos tuntud üle aia hüppamisega seotud lastemängus, milles viimaseks jäänule üteldi: „Aian akka, pellon pekka, / Viipurin venehen nokka” (või „kokka”, fraasi viimased sõnad võisid varieeruda, vt Haavio 1959: 122). Paralleel setode Peko-traditsioonis tuntud ja vereliisuga seotud üle aia hüppamisega on ilmne. Pekot teati varem ka Vadjamaal, kus öine lastepainaja kandis riiga pekko ('rehe peko') nime (Honko 1962: 362-364). Sageli on mälestused muistsetest jumalustest ja vaimolenditest edasi kestnud laste mängudes või lastehirmutisena.

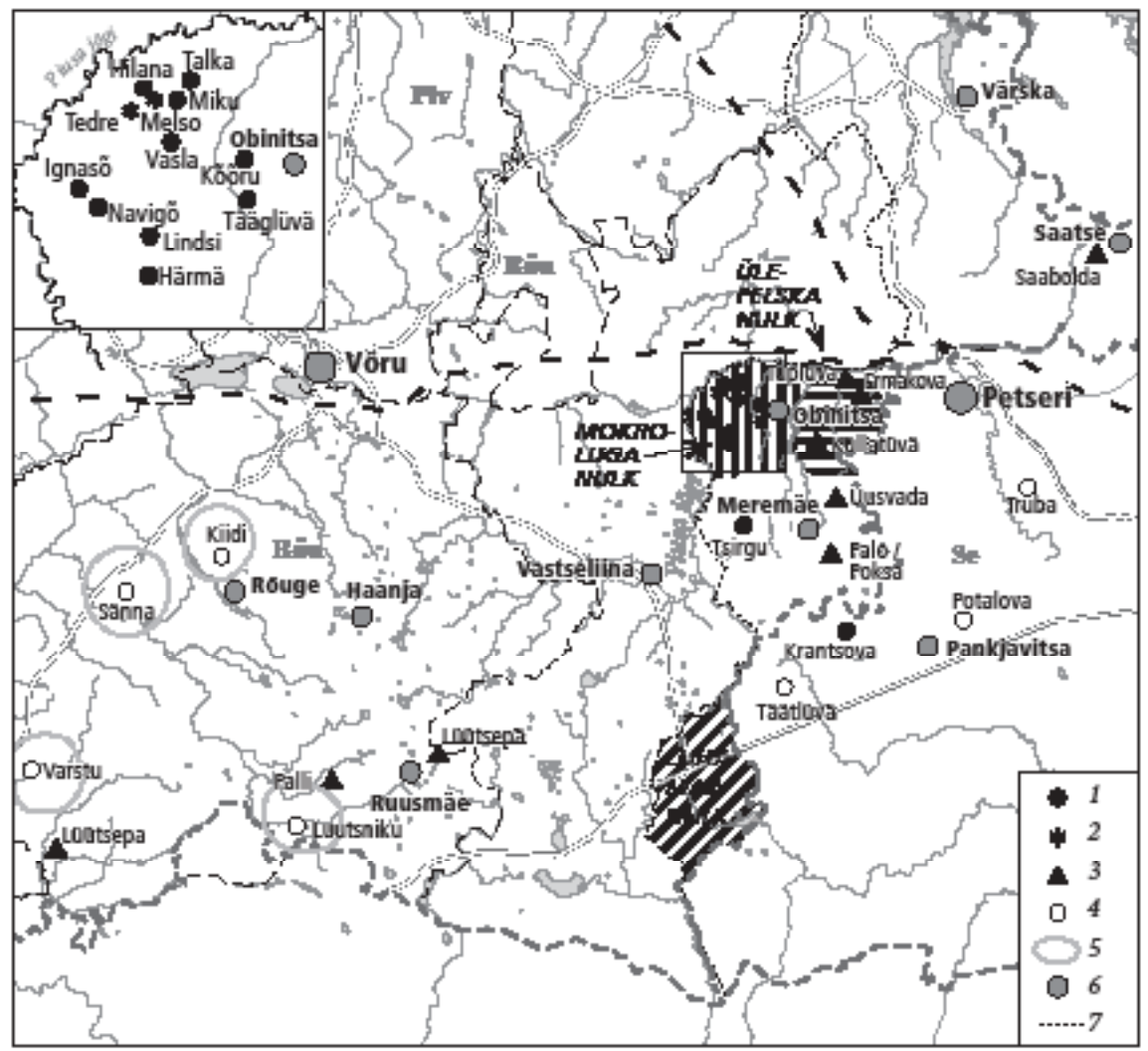

Kaart 1. Pekot austanud ja Peko või puujumala kujuga külad. 1 - varasemad teated Peko austamisest Paul Hagu (1997) ja Ergo-Hart Västriku (2017) järgi, 2 Liidia Sillaotsa (2008) lisandused, 3 - varem avaldamata uued teated, 4 - teised tekstis mainitud külad, 5 - kesväesä sõna Võrumaal, 6 - suuremad asulad, 7 Setomaa ja Võrumaa piir. Vormistus: Jaana Ratas. 
Arvestades karjala ja vadja traditsiooni ning Võrumaa puujumalaid ja kesväesä, on Peko või temataolise muinasjumala austamise areaal olnud kunagi palju suurem, kuid ajapikku kokku tõmbunud, piirdudes lõpuks Mokornulgaga. 1990. aastate alguse seisuga oli tõsikindlaid andmeid Peko kohta Hilana, Härmä, Ignasõ, Kõõru, Lindsi, Miku, Navigõ, Tal’ka ja Tääglüvä külast (kaart 1) (Hagu 1997: 36-37). Anastassia Kera (snd 1874) teatel lisanduvad Peko külade hulka Mokornulgast veel Melso ja Tedre - seal, nii nagu Ignasõlgi, olnud Peko palujaid rohkem kui Vaslas (Sillaots 2008: 81). Eisen (1906: 387) märgib Härmä kõrval teise külana, kus Pekot kõige enam austati, veel Tsirgut, mis leidub ka Peko kultuse uusimal levikukaardil (Västrik 2017: 520, joonis 5). ${ }^{21}$

Ülaltoodud pärimus- ja mälestuskillud avardavad mõneti Peko kultuse leviku senist pilti (kaart 1). Muistset jumalat pole Setomaal austatud mitte ainult Mokornulgas, Tsirgul, Krantsovas ja Luhamaal, ${ }^{22}$ vaid viiteid sellele leidub ka Krantsova ümbrusest ning Üle-Pelska nulga Küllätüvä, Ermakova ja Tupl'uva küladest, Mokornulga idapiirist vastavalt 1, 5 ja $3 \mathrm{~km}$ kauguselt.

Mälestused Küllätüvä ja Krantsova Pekost ei räägi enam ühistest pidustustest, vaid kuju varjatud liikumisest talude vahel - puukuju viidi õnnetuste ja hädade korral sinna, kuhu parasjagu vaja oli. Tõenäoliselt rajaneb see samuti varasemal traditsioonil, kuigi asjakohaseid näiteid pole rahvaluulekogudest õnnestunud leida. Linnupuu Anne (Uusvada) eespool mainitud teade, et kuju toodi Obinitsast, viitab sellele, et veel 1930. või isegi 1940. aastatel võis Peko austajaid olla kirikukülaski. Siiski võib kohanimi esineda ka ülekantud tähenduses ja silmas võidi pidada mõnda teist küla Obinitsa lähedal.

Krantsova Peko ei asu nüüd enam sedavõrd üksi ja eraldi kui varem. Tõenäoliselt ei kajasta teade kuju hädaolukorras Poksa või Palo külla viimisest erandjuhtumit, vaid sarnaselt Küllätüväga otsiti sel viisil abi laiemaltki. Nii avaneb uus, Krantsovast lähtunud suhtlusring, mis asetab uude valgusse ka teated Luhamaa kohta. Ühtaegu ilmneb, et Krantsovas, kus pärimus jumalakujust piirdus seni mälestusega selle hoidmisest aidas vilja sees ja tõdemisega, et „küll ta ikka üks hea asi on” (Ränk 1934: 176-177), oli kuju kasutusel siiski veel üsna hiljuti. Samas võivad jutud Ignasõ Peko viimisest Krantsovasse kajastada sealsete Peko pidajate sidemeid Mokornulgaga. Tsirgu küla,

${ }^{21}$ Paul Hagu ei ole 1970. aastatel Tsirgu küla vanematelt inimestelt Peko kohta midagi kuulnud, mistõttu pole sealseid teateid peetud usaldusväärseks (Hagu 1997: 37). Kuna Peko kultus oli varjatud ja seostus lõppjärgus vaid kindlate taludega, ei saa mälestuste puudumist pidada siiski veenvaks argumendiks. Näiteks ei ole Härmä külas viiendat põlve kohalik ja traditsiooni väga hästi tundev Aksel Haavik (snd 1944) oma vanematelt kuulnud, et külas oleks Pekot olnud. Samas teadis Hilläkeste külas Kuldnoka Kati (snd 1911) veel 1994. aastal kõnelda Pekost Haavikute nüüdseks hävinud naabertalus (EKM ERA, FAM 130 (3)).

${ }^{22}$ Leonid Zurovi Setomaa 1937.-1938. aasta välitööaruandes on nimetatud ka puujumala austamist Täätlüvä külas (Zurov 2017 [1946]: 274, 276, 315). Tegemist pole siiski Täätlüvä (Дятлово), vaid Mokornulka kuuluva Tääglüvä (Дяглово) külaga. Kui Zurov 2017 [1946]: 274 toodud Täätlüvä tuleneb sellest, et venekeelses masinkirjatekstis algselt olnud Tääglüvä on autor ise käsitsi valeks parandanud, siis Zurov 2017 [1946]: 276 on Täätlüvä mainimise põhjuseks masinkirjateksti arvutisse sisestamisel tehtud viga, mis on kandunud ka eestikeelsesse tõlkesse (vt http://zurov.ut.ee/sites/default/files/zurov/files/13-3_zurovi_ aruanne_2.pdf, lk 27, 28 ja 74 (24. II 2019)). Sellele, et kirjanik on külade nimed tõenäoliselt segamini ajanud, on raamatus ka tähelepanu juhitud (Zurov 2017 [1946]: 274, viide 66; Västrik 2017: 518-521). 
kus Eiseni teatel Peko kultus oli väga tugev, jääb kahe nimetatu vahele. Ignasõ ja Krantsova seosed peegelduvad ka sõnades, mida Seto Kuningriigi päevadel on Peko kohta laulnud Hõpõhelme' koori Tääglüväst pärit eestlaulja Olga Tiik (1922-2017). 1997. ja 2001. aastal Luhamaal salvestatud tekstides leiduvad järgmised read: „Peko karas vällä Krantśuvast, / Mokorlukka küüsse tiid. / Pruuvsõ olla küll Mokornukah, / inäbüisi olli Ignasilla" (20 aastaka...: 60) ja „Peko-ks, Peko inämbidsi elli Krantsuvah, / äkki-ks, äkki karas tä vällä Krantśuvast, / Mokor-, Mokornukka küüsse, küüsse tiidä, / ärä-ks, ärä ihas tä Ignassilõ, / tiidse-ks, tiidse tiid tä Tõnisõ poolõ [---]" (20 aastaka...: 113). Tõnise talu on Ignasõl Otsa naabertalu. Laul näitab, et ka seal osaleti Peko „tõstmistes”.

Vastamata jääb küsimus, miks käis Ignasõ Peko praasnikul Potalovast pärit naine - seda enam, et tema Ignasõlt pärit mees seda ei teinud. Kas on tegemist üksnes hea sulandumisega uue koduküla ellu või peitub selle taga lapsepõlvest pärinev teadmine Pekost kui õnneandjast jumalast? Krantsovast on Potalovasse ligi kaheksa kilomeetrit. Samuti jääb teadmata, kas Saatse lähedal Saaboldas talupööningult leitud kuju oli tehtud kohapeal või oli viidud sinna juba kunagi ammu Mokornulgast, näiteks koos koduväiga või siis vajaduse korral kaugemalt abiks tooduna, kuid aegade muutudes tagasi viimata jäänud.

Kui mitte arvestada Saabolda kuju, mis võis oma leiukohas lebada juba põlvkondi, koonduvad pärimusteated Pekost setode asuala lõunaosa lääneserva. Et Peko austamine kestis kõige kauem Mokornulgas ning üsna kaua ka Tsirgul, Krantsova ümbruses ja nähtavasti ka Luhamaal, ei ole juhus. Kuigi Eesti poolt vaadates on need piirkonnad lähedased, on õigeusu kultuuriruumis tegemist kaugete ääremaa nurkadega vastu võõrausulist Liivimaa kubermangu. Et Luhamaal on mälestused vanadest jumalatest kaua püsinud, kinnitab ka ütlus „Noid pelgät nii ku vannu jummalit!”, mida kuulsin 1998. aastal. Tõenäoliselt andis just Peko kultus põhjust Taeluva koguduse ääremaadele 1897. aastal Obinitsa kool-kiriku ehitamiseks. Suuremas pildis on Peko kauane austamine siiski üsna lokaalne nähtus. Kaudselt kinnitab seda tõik, et XX sajandi alguses Setomaa eri piirkondadest Siberisse välja rännanud setode seas oli Peko tundmatu: Mare Piho aastatel 1987-2004 toimunud 14 uurimisretkel ei õnnestunud vaatamata järjekindlale küsitlemisele saada Pekost mingeid teateid ja nimigi oli küsitletavatele tundmatu (Mare Piho, 2018*). Põhjus võib olla traditsiooni kustumises, kuid arvatavasti eeskätt selles, et Pekot austati juba väljarändamise ajal vaid väga kitsal alal.

Vastu ootusi on puujumala geograafia avardunud aga lääne suunas, väljapoole Setomaa piire, Rõuge kihelkonda, kus kindlamaid andmeid jumalakujudest on Palli ja Lüütsepä küladest. Mõlemal juhul on kuju olnud ühe pere valduses: Pallil „vanaisa oma”, Lüütsepäl „perekonna heaolu jumal”. Kuigi Pallil ei saa Peka nimes välistada loetu või kuuldu teisenenud tagasipeegeldust, väärib rõhutamist, et jutustaja oli täiesti kindel $a$-lõpulise nimekuju õigsuses. Sõnalõpu $a$ ja $o$ varieeruvad ka Ida-Soome, Karjala ja Ingerimaa pekko/pekka traditsioonis. Ehk on tegemist hoopis kunagise ühispärandi viimase kajastusega?

Mujalt Võrumaalt seni teated puujumalast puuduvad, kuid kuna Pekot on seni seostatud üheselt Setomaaga, pole välitöödel tema kohta ka küsitud. Siin- 
kohal nimetagem taas Võrumaa kesväesä ja seda, et Agricola põllupekodki olid odrakasvu andjad. Ehk on heal lapsel mitu nime? Võrumaa andmeid arvestades näib üha usutavam, et varem võis Peko või lähedase tähendusega jumalus, paiguti ehk erinevalt nimetatu, olla tuntud ka kaugemal Kagu-Eestis. Paul Hagu on Peko kunagist tuntust oletamisi seostanud Võrumaa idaosa, Setomaa ja Peipsi-taguste V/VI-IX/X sajandi kääbaste levialaga (Hagu 1997: 40), st Kagu-Eesti ja Ingerimaa vaheliste, praeguseks venestunud maadega. Nii Eesti kui ka Venemaa arheoloogid on veendunud, et kõikjal oli tegemist ühe ja sama rahvaga. Nii saavad ka Peko/Peka traditsioonis kokku idapoolse läänemeresoome ruumi üksteisest praeguseks ammu eraldatud otsad.

\subsection{Peko ja inimesed}

1930. aastad tõid kaasa elu kiire muutumise Setomaal (Lõuna 2003; Grichin 2003) ning Pekoga seotud isikute arv vähenes ruttu. Kui 1931. aastal osales Ignasõl kitsamas ringis toimunud palvusele järgnenud Peko pidustustel 30 perekonda (Vanas usus...), siis 1935. aasta paiku oli Linnupuu Anne (Tääglüvä) teatel osavõtjaid vaid umbes kuus oma küla vanainimest.

Ülalkirjeldatu aitab tuua selgust Peko kultuse lõppemise aja ja viiside kohta. Väärib rõhutamist, et nii Ignasõ, Küllätüvä kui ka Krantsova Peko kujud ringlesid veel pärast sedagi, kui peremeest enam ei valitud. Kuju polnud nüüd enam aastaks ühe pere valduses, vaid liikus asjaosaliste arvatavalt üsnagi suletud ringis talust tallu. Sealjuures toimus Ignasõl kuju „tõstmine” lõpuks üsna lühikese aja tagant (lapse ajamääratluses kas nädäli pärast vai võib küll kahelda), teistel juhtudel vastavalt vajadusest abi järele. Ühe Hilanalt pärit teate järgi andis Peko unes ise sellest märku, et kuju tuleb „liigutada", st koos pidustustega teise tallu viia (EKM ERA, RKM II 44, 503/6 (1), Matro Uibokand, 70 a (1953)).

Peko viimaste austajate taust ja maailmavaade pole varem tähelepanu pälvinud. Paradoksaalselt oli enam kui 40 aastat Ignasõ Pekot salamisi hoidnud ja palunud Otsa Petra samal ajal Obinitsa preestri abiline ja kirikuvanem, sügavalt usklik ristiinimene. Kuigi selline kombinatsioon võib tunduda ilmvõimatu, ei lähe kaks usku, vähemasti inimese enese vaatenurgast, vastuollu, andes tunnistust võimaluste paljususest rahvausundi maailmas. Rahvapärane religioossus avaneb erinevates, kuigi kiriku seisukohast vastandlikes suundades. Peko kultuse laiematki seostumist kirikuga kinnitavad Anne Linnupuu sõnad (Uusvada, 1993*): „Ja Pekot väga paluti, täämbä naasõ' kõnõli’. Ütskõik kelle poolõ sis tuu Peko viidi, sis minti sinna kokku ja Peko pääle peeti palvust. Kiriku palvust. Kiriku palvust, jah Peko pääle peeti. Mina toda-as tiia.” Anne ravijast vanaema, kes Küllätüvä Pekot talust tallu toimetas, käis iga pühapäev külatsässonas, lapselapsigi kaasa võttes. Rikka-Ivvani talu viimane vanaperenaine, kes Pekot võõrale ei näidanud, oli sarnaselt põlvkonnakaaslastega küll kirikuga seotud, kuid jõudis sinna harva, „ehk mõned korrad aastas”. Samal ajal oli Ermakovas Mägi peresse kuuluv, nõiaks peetud Kull’o ristiusule vastanduva vana elutunnetuse kandja ja õigete ristiinimeste hulka pole külarahvas arvanud ka Tupl'uvas puujumalat pidanud peret. Seega saab üldistavalt tõdeda vaid asjaosaliste väga erinevat suhet kiriku ja õigeusuga. Me ei tea, 
kas mitmel juhul ilmnev, eri algupäraga uskumuste rahvapärane harmoonia seostub vaid lähema minevikuga, iseäranis XX sajandiga, mil setode maailmapilti vormisid ka kooliharidus ja kirjakultuur, või on sellel märksa sügavamad juured.

\section{Lõpetuseks}

Kuigi aegade muutumine tõi kaasa Peko lahkumise, ulatub muistse jumala austamine - kuju hoidmine ja võõraste eest varjamine - üsna lähedasse minevikku. Kahtlemata pidas Otsa Petra Navigõl Pekot kuni oma surmani aastal 1980 ja kuju kadumine tühjaks jäänud majast osutab sellele, et jumalal oli tähendus hiljemgi. Ka Küllätüvä Rikka-Ivvani talu vanaperenaine ei olnud nõus veel 1993. aastal võõrale kuju näitama.

Artikkel teeb kokkuvõtteid sellest, millised muutused toimusid Peko kultuse lõppvaatuses pärast pidustuste ja ühiste palvuste hääbumist. Varem ringluses olnud jumalakuju jäi nüüd hoiule ühte tallu. Kiiresti muutuvate aegade ja vana ilmaga seotud põlvkonna lahkumise üldises raamistuses (Valk 1996) osutus üks „tõstmistest” või kuju abivajajate juurde viimistest paratamatult viimaseks. Peko alaliseks asupaigaks saanud talus võis teadmine jumalast kaduda koos viimase vastavasse põlvkonda kuuluva, temast hooliva ja kuju tähendust teadva asjaosalisega.

Peko kujude edasine käekäik on olnud erinev. Pärast oma hooldaja surma võis puujumal jääda majapidamise vanakraami hulka, jagades aja möödudes kaduva mateeria vältimatut saatust. Juhul kui kujust teadjate ring oli suurem, võis see aga pärast valdaja lahkumist leida endale kas uue hoiupaiga või ostja. Aimates ette oma peatset lahkumist, võis jumalakuju viimane hoidja, teadlikuna oma rollist, vastutusest ja aegade muutumisest, selle aga ka juba aegsasti olematusesse suunata.

Ajastud vahetuvad, koos nendega ka uskumused, kombed ja inimesed. Traditsioonipõhine teadmine Pekost ja mälestused kokkupuudetest temaga on Setomaalt tänaseks peaaegu kadunud - enamasti võib hea õnne korral kohata vaid jutukatkeid ja mälestuste mälestusi. Saabunud on uus aeg ja Peko nimigi on saanud uue tähenduse. Jumal Pekost on saanud eepose Peko, kes magab Petseri kloostrikoobastes, täites ühtaegu kindlat rolli ja uut ülesannet - olla Setomaa ühendaja ja vajaduse korral abistaja.

Muutunud aeg ja asjaolud annavad põhjust meelde tuletada Pekot ka sellena, kes ta oli algselt, enne Setomaa uut ärkamist. Mitte rahva ja rahvuse uinunud heeroskuningana, kes ootab kloostris oma teist tulemist, vaid Setomaa taludele argielus abi andnud elava jumalana, keda vähemasti traditsiooni lõppjärgus võidi austada kõrvuti kristliku maailma vägedega või ka rahvapärase õigeusu maailmavaate avaras raamistuses. Jumalana, kellest võõrastele ja võõraste ees ei räägitud.

Artkkel on kirjutatud Haridus-ja Teadusministeeriumi institutsionaalse uurimisteema IUT20-7 „Eesti Läänemereruumis: majanduslike, sotsiaalsete ja kultuuriliste protsesside arheoloogia” raames ja toetusel. Peko teadete leidmiseks on kasutatud Eesti Rahvaluule Arhiivi kohapärimuse andmebaasi. Tänan 
kõiki Setomaa inimesi, kes selle ülevaate saamisele kaasa aitasid, eriti mõlemat Anne Linnupuud - Uusvadast (†) ja Võrust/Tääglüväst, Heino Keskküla Lasvalt / Ermakovast, Aare Hõrna Antkruvast, Paul Hagu Tartust, Vassili ja Liia Lillepuud Küllätüväst, Aksel Haavikut Härmält, Anni Lahet Meremäelt, Paul Leostet Ignasõlt, Eve Ellermäed Obinitsast, skulptor Renaldo Veeberit Samarinnast/Tallinnast (†), samuti Tõnu Suuveret ja Ago Petäid Võrust, Valdur Tanilsood Luutsnikult, Aigar Pihot Kiidilt ning Leho Ainsaart, Kristi Salvet, Ergo-Hart Västrikku, Freydis Ehrlichi ja Taisi Juusi Tartust.

\section{Arhiiviallikad ja muuseumikogud}

Eesti Kirjandusmuuseumi (EKM) Eesti Rahvaluule Arhiiv (ERA): EKRK - Eesti kirjanduse ja rahvaluule kateedri kogu

ERA - rahvaluulekogu

FAM - helikassetikogu

RKM - Riikliku Kirjandusmuuseumi kogu

Obinitsa Muuseum (Setomaa Muuseumid) (OSM)

Rahvusarhiiv (RA)

EAA.5433.1.7 - Petseri valla elanike perekonnanimede panemise protokollid, 1921.

\section{Käsikirjad}

Remmel, Raivo 1982. Küllatova Rikka-Ivani ja Lintsi Andre hõimude kroonika. Elva. Käsikiri Vassili Lillepuu valduses Küllätüvä külas.

Re m mel, Raivo 1988. Küllatova Rikka-Ivani ja Ode suguvõsa liikmete nimekiri seisuga 15. juuni 1988. aastal. Elva. Käsikiri Vassili Lillepuu valduses Küllätüvä külas.

Vahelaan, Paul [2004]. Uma Uusvada. [Tõravere]. Käsikiri Paul Sõrmuse (Tartu/Vasla) valduses.

\section{Andmebaasid}

FES = Eesti fraseologismide elektrooniline alussõnastik. http://www.folklore.ee/ justkui/sonastik (14. II 2019)

\section{Kirjandus}

20 aastaka Seto Kuningriike sõnolisi laulu'. (Seto Kirävara 11.) Toim Õie Sarv. [Värska]: Seto Instituut, 2015.

Agricola, Mikael 1987. Mikael Agricolan teokset. 3. osa. Käsikirja; Messu eli herran Echtolinen; Se meiden herran Iesusen Christusen Pina; Dauidin Psaltari; Weisut ia Ennustoxet; Ne Prophetat. Haggaj. Sacharia. Maleach. Porvoo: Söderström. 
Eesti Rahva Muuseum sai setu ebajumala. - Uus Eesti 27. VIII 1938.

Eisen, Matthias Johann 1906. Über den Pekokultus bei den Setukesen. - Finnisch-ugrische Forschungen: Zeitschrift für finnisch-ugrische Sprach- und Volkskunde, kd 6, lk 104-111.

E i s e n, Matthias Johann 1908. Setukeste jumal Peko. - Eesti Kirjandus, nr 11, lk 377-387.

Eis en, Matthias Johann 1936. Peko. - Õpetatud Eesti Seltsi Aastaraamat 1934. Tartu: Õpetatud Eesti Selts, lk 1-16.

Grichin, Kadi 2003. Riiklik poliitika Petserimaa usuelu korraldamises 1920.1930. aastatel. - Õpetatud Eesti Seltsi aastaraamat 2000-2001. Tartu: Õpetatud Eesti Selts, lk 167-181.

Haavio, Matti 1959. Karjalan jumalat. Uskontotieteellinen tutkimus. PorvooHelsinki: Werner-Söderström OY.

Hag u, Paul 1975. Setu viljakusjumal Peko. - Keel ja Kirjandus, nr 3, lk 166-173.

Hag u, Paul 1997. Peko-kultusõ varahamp (arvatav) tuntus. - Õdagumeresoomõ lõunapiir. Läänemeresoome lõunapiir. Itämerensuomen eteläraja. Konverents Kütioron, märdikuu 28.-30. 1996. (Võro Instituudi toimõnduseq 1.) Toim Karl Pajusalu, Jüva Sullõv. Võru: Võro Instituut, lk 32-42.

Harva, Uno 1948. Suomalaisten muinaisusko. Porvoo-Helsinki: Werner-Söderström OY.

Honko, Lauri 1962. Geisterglaube in Ingermanland. (Folklore Fellows Communications 185.) Helsinki: Suomalainen tiedeakatemia.

J aik, Juhan 1999. Kesväesä. - Akadeemia, nr 1, lk 72-76.

Lõ u n a, Kalle 2003. Petserimaa. Petserimaa integreerimine Eesti Vabariiki 19201940. Tallinn: Eesti Entsüklopeediakirjastus.

Riits a a r, Evar 2006. Rahomiilne vaimujummal. Riitsaarõ Evar kõnõlõs Veeber Renaldoga. - Peko Helü, nr 1, lk 16-17.

Ränk, Gustav 1934. Materiaalne Peko. - Eesti Rahva Muuseumi aastaraamat, IX-X. Tartu, lk 177-203.

S a n d r a, Jaan, 1908. Ristirahva ebajumal Peko. - Ristirahva Pühapäeva-leht, nr 42, 16. X; nr 43, 23. X.

Setomaa kohanimed. Koost Arvis Kiristaja. (Seto Instituudi toimetised 1.) [Värska:] 2013.

Sill a ots, Liidia 2008. Om üts Mokornulk. - Setumaa kogumik 4. Uurimusi Setumaa loodusest, ajaloost ja rahvakultuurist. Koost Mare Aun, Merlin Lõiv, toim Ülle Tamla. Tallinn: Tallinna Ülikooli ajaloo instituut, lk 67-92.

S peek, Peeter A. 1930. Mälestusi vana-eestlastest, II. Setud ja nende kodujumal Peku. - Eesti Noorus, nr 9, lk 148-152.

Tru u s man n 1890 = Jurij Trusman, Poluvercy Pskovo-Pečerskago kraja. - Živaja starina, kd 1, nr 1, lk 31-62. [Юрий Трусман, Полуверцы Псково-Печерскаго края. - Живая старина, 1:1, 31-62.]

Z u r ov, Leonid 2017 [1946]. Petseri maakonna setu ja vene talupoegade ristiusueelsetest iganditest ja religioossetest uskumustest. Kivide, allikate ja puude austamisest. - Inimese Muuseumi ekspeditsioonid Eestisse. Boris Vilde ja Leonid Zurov Setomaal (1937-1938). (Seto Instituudi toimetised 2.) Koost ja toim Tatiana Benfoughal, Olga Fišman, Heiki Valk. Tartu: Tartu Ülikooli ajaloo ja arheoloogia osakond, Seto Instituut, lk 251-318. 
Valk, Heiki 1996. Aegadest ja ajatunnetusest Setomaal. - Palve, vanapatt ja pihlakas. Setomaa 1994. a. kogumisretke tulemusi. (Vanavaravedaja 4.) Toim H. Valk, Ergo Västrik. Tartu: Tartu NEFA, lk 59-92.

Valk, Heiki 1999. Mälestusi Meeksi jaanipäevast. - Mäetagused, nr 9, lk 146-174. Vanas usus on ürgjõudu. - Elu. Võru-Petserimaa häälekandja, nr 42, 6. VI 1931.

V e e b e r, Natjalja 2014. Seto teema kunstnik Renaldo Veeberi loomingus. - Setumaa kogumik 6. Uurimusi Saatse Seto Muuseumi auks. Tallinn-Saatse, lk 69-78.

Västrik, Ergo-Hart 2017. Setode ristiusueelsed traditsioonid. - Inimese Muuseumi ekspeditsioonid Eestisse. Boris Vilde ja Leonid Zurov Setomaal (19371938). (Seto Instituudi toimetised 2.) Koost ja toim Tatiana Benfoughal, Olga Fišman, Heiki Valk. Tartu: Tartu Ülikooli ajaloo ja arheoloogia osakond, Seto Instituut, lk 511-522.

Heiki Valk (snd 1959), PhD, Tartu Ülikooli ajaloo ja arheoloogia instituut, vanemteadur(Jakobi 2, 51005 Tartu), heiki.valk@ut.ee

\section{Departure of the Seto God Peko}

Keywords: Peko, Setomaa, popular Orthodox Christianity, popular religion, fertility god

The cult of the Seto pre-Christian fertility God Peko has attracted research attention both from descriptive (Eisen 1909; 1936) and analytical aspects (Ränk 1933; Hagu 1975, 1997; Västrik 2017), the latter concentrating upon its geographical distributon and context among Finno-Ugric and Finnic deities. This article, based mainly on information collected in Setomaa since the 1990s, sheds light upon its latest phase of retreat and disappearance. The cult of Peko survived the longest in the small district of Mokornulk west of Obinitsa church village, historically extreme periphery of the Orthodox Pskov Government against the border of the Lutheran Government of Livonia.

Last communal sermons of Peko were held in the hamlet of Ignasõ, $3 \mathrm{~km}$ southwest of Obinitsa, for the last time in the midle of 1930s when then the circle of participants was limited to ca. 6 old people from the same village. A living witness of the event remembers how women brought food to the idol covered by white cloth. Although the wooden image of the god disappeared from the public in the late 1930s already, it was kept and secretly worshipped by Peeter Ots (Otsa Petra) (1900-1980) (Fig. 1) in the neighbouring Navigõ hamlet until the end of his lifetime. The fact that the man was simultaneously a true and deeply religious Orthodox Christian, for years also the assistant of the priest of Obinitsa Church, gives evidence of the broad spectrum of vernacular religion.

Another image of Peko which was widely used to get help in case of misfortune, trouble or poverty as late as in the late 1930s was secretly kept in Küllatüvä village until the late 1990s. In Ermakova village Akulina Mägi, a local healer (Fig. 3) used a wooden idol and a man-shaped image of rye straw (Figs. 4, 5) in rites related to first-time taking the cow out to the pasture in spring. Data of wooden idols, similar to Peko are also known from Setomaa from Saabolda hamlet, as well as from Lüüt- 
sepä (Fig. 6) and Palli hamlets near Ruusmäe/Rogosi manor in the southern part of Rõuge parish (Võrumaa) - also in remote periphery, near the Latvian border.

The new data give evidence of broader distribution of the cult of Peko when compared to what was known before (Map 1), as well as about its longer duration. Although in Palli the image was called Peka, it must be noted that the variations Pek $(\mathrm{k}) \mathrm{o} / \mathrm{Pek}(\mathrm{k}) \mathrm{a}$ occur also in the tradition of eastern Finland and Karelia where the name also designates some supernatural being(s). Presumably, the cult of Peko relates to a broader ancient eastern Finnic tradition which once stretched from eastern Finland and Karelia over Ingermanland and lands east of Lake Peipsi to south-eastern Estonia.

Although during the last decades Peko has obtained a new meaning among the Seto community - that of the sleeping god-king of whole Setomaa, waiting for its resurrection and new coming in the caves of Pskovo-Petchersky monastery - the topic of Peko as a god of the past is sometimes still not open for aliens.

Heiki Valk (b. 1959), PhD, University of Tartu, Institute of History and Archaeology, Senior Research Fellow (Jakobi 2, 51005 Tartu), heiki.valk@ut.ee 